\title{
Ferns of the Lower Jurassic from the Mecsek Mountains (Hungary): taxonomy and palaeoecology
}

\author{
Maria Barbacka $^{1,2} \cdot$ Evelyn Kustatscher ${ }^{3,4,5} \cdot$ Emese R. Bodor $^{6,7}$
}

Received: 7 July 2017 / Accepted: 26 July 2018 / Published online: 20 September 2018

(c) The Author(s) 2018

\begin{abstract}
Ferns are the most diverse group in the Early Jurassic plant assemblage of the Mecsek Mountains in southern Hungary and, considering their abundance and diversity, are an important element of the flora. Five families were recognized so far from the locality; these are, in order of abundance, the Dipteridaceae (48\% of collected fern remains), Matoniaceae (25\%), Osmundaceae (21\%), Marattiaceae (6\%) and Dicksoniaceae (three specimens). Ferns are represented by 14 taxa belonging to nine genera: Marattiopsis hoerensis, Todites princeps, Todites goeppertianus, Phlebopteris angustiloba, Phlebopteris kirchneri Barbacka and Kustatscher sp. nov., Matonia braunii, Thaumatopteris brauniana, Clathropteris meniscoides, Dictyophyllum nilssoni, Dictyophyllum rugosum, Cladophlebis denticulata, Cladophlebis haiburnensis, Cladophlebis roessertii, and Coniopteris sp. Ferns from the Mecsek Mts. are rarely found in association with other plants. They co-occur mostly with leaves of Nilssonia, leaflets of Sagenopteris, and rarely with other plants. The most commonly co-occurring fern species is P. kirchneri Barbacka and Kustatscher sp. nov. According to our statistical approach (PCA, Ward cluster analysis), the fern taxa cluster in four groups corresponding to their environmental preferences, determined by moisture and disturbance. Most taxa grew in monospecific thickets in disturbed areas; a few probably formed bushes in mixed assemblages, whereas one taxon, P. kirchneri, probably was a component of the understorey in a stable, developed succession of humid environments.
\end{abstract}

Keywords Hettangian $\cdot$ Pteridophyta $\cdot$ Plant associations $\cdot$ Palaeobiogeography $\cdot$ Palaeoenvironment $\cdot$ Statistics

\section{Introduction}

The Mecsek Mountains (southern Hungary) are well known for their mining activities since the nineteenth century (e.g., Hantken 1878; Barbacka 2011). These mining activities were developed on Triassic-Jurassic rocks near the city of Pécs, yielding thousands of plant remains (e.g., Beudant 1822; Barbacka 2011). Systematic collecting of

Electronic supplementary material The online version of this article (https://doi.org/10.1007/s12542-018-0430-8) contains supplementary material, which is available to authorized users.

Maria Barbacka

barbacka.maria@nhmus.hu

Evelyn Kustatscher

Evelyn.Kustatscher@naturmuseum.it

Emese R. Bodor

emesebodor@gmail.com

1 Botanical Department, Hungarian Natural History Museum, P.O.Box 137, Budapest 1431, Hungary

2 W. Szafer Botanical Institute Polish Academy of Sciences, ul. Lubicz 46, 31-512 Kraków, Poland

3 Museum of Nature South Tyrol, Bindergasse 1, 39100 Bolzano/Bozen, Italy
4 Department für Geo- und Umweltwissenschaften, Paläontologie und Geobiologie, Ludwig-MaximiliansUniversität, Münich, Germany

5 SNSB-Bayerische Staatssammlung für Paläontologie und Geologie, Richard-Wagner-Straße 10, 80333 Munich, Germany

6 Institute for Geological and Geochemical Research Research Centre for Astronomy and Earth Sciences, Hungarian Academy of Sciences, Budaörsi út 45, Budapest 1112, Hungary

7 Department of Paleontology, Eötvös Loránd University, Pázmány Péter sétány 1/c, Budapest 1117, Hungary 
plant remains has been carried out since 1989 (e.g., Barbacka 1991, 1994a, b, 2001, 2002, 2009). Palaeobotanical studies include basic taxonomy (e.g., Barbacka 1991, 1994a, b, 2009; Barbacka and Bóka 2014), considerations on intraspecific variability of plants (e.g., Guignard et al. 2001; Barbacka and Bodor 2008; Bodor and Barbacka 2008) and palaeoecological/palaeoenvironmental reconstructions (Barbacka 2011; Barbacka et al. 2014). The palaeoecology was based on preferences of the plant remains (more than 700 slabs) regarding the co-existence of taxa on the same slabs, the paleoenvironment was inferred from taxa connected to selected lithologies and their spatial distribution.

The flora comprises at least 55 taxa of leaves, reproductive organs, seeds or trunks belonging to all major plant groups (Barbacka 2011) and shows a higher variability on higher systematic level (families or genera) than on species level. Fern remains are very common, with a higher relative abundance than relative species richness. They are usually considered indicators for humid environments because their reproductive cycle is strongly linked to moisture (at least the gametophytes) although some extant ferns are adapted also to more arid environments (Van Konijnenburg-van Cittert 2002 and ref. therein). This has been observed also in some fossil ferns of Hungary (Barbacka 2011).

The aim of this study is to increase our comprehension of the biodiversity of the Jurassic flora of the Mecsek Mountains by unraveling one of its main components, the ferns. Co-occurrence analyses of ferns with other plant groups gives insights into Jurassic biocoenoses. The flora from the Mecsek Mountains is a good object for such a study since its plant assemblages can be considered (par-)autochthonous (e.g., Barbacka 2011), permitting us to determine the palaeoecological preferences of single taxa and to reconstruct the palaeoenvironmental conditions the plants grew in.

\section{Geology, materials and methods}

Jurassic sediments rich in plant macrofossils are confined in Hungary to the coal-bearing horizons of the Mecsek Coal Formation (Hetényi in Császár 1997) of the Mecsek Mountains (Baranya County, southern Hungary; Fig. 1). The coal seams of the Mecsek Coal Formation are Hettangian in age (Góczán 1956; Földi 1967; Paál-Solt 1969; Nagy and Nagy 1969; Szente 1992; Landis et al. 2003), although, thin coal seams appear already in the fluvial succession of the latest Rhaetian (Hetényi in Császár, 1997). During the Early Jurassic, a fluvial-lacustrine-palustrine environment was formed, and paralic coal-swamp deposits became dominant. Plant beds alternate occasionally with mollusc-bearing marine sublittoral layers. Crinoids appear in the upper part of the formation, indicating open marine conditions. The coalbearing area extends in $\mathrm{N}-\mathrm{S}$ direction, over a distance of about $20-30 \mathrm{~km}$, from Nagymanyok to Pécs, constituting a mining region of $350-400 \mathrm{~km}^{2}$. The sedimentary succession might change in facies within the same locality (shafts and open mines) and within short distances due to tectonic activity and strong subsidence (Nagy and Nagy 1969). Unequal (synsedimentary) subsidence caused differences in thickness and carbonization degree of the various coal deposits (Nagy and Nagy 1969) with a lowest thickness near Nagymányok $(120 \mathrm{~m})$, increasing gradually southward (Pécs; 1000-1200 m thick, for more details see Barbacka 2011).

Mining activities in the Mecsek Mountains have been ongoing for more than 200 years with an intense exploration period between 1960 and 1990. In 2004 the underground mines were closed and open mining stopped. More than 5000 rock slabs with plant fossils were collected in the years 1989-2004 by one of the authors (MB); 805 fern remains were identified and used for this study. They are represented generally by frond fragments, often of large dimensions. The specimens are preserved in siltstone, shaly siltstone, fine detritic siderite and carbonate sandstone (Bodor and Barbacka 2008). Most frond fragments are preserved as impressions; (highly) coalified organic material is rare. Details are well visible in the fine sediments, although in situ spores are not preserved.

The plant fossils originate from different sites all over the Mecsek Mountains, both from open cast mines (e.g., Pécs-Vasas, Pécsbánya) and dumps of deep shafts (e.g., Béta, Zobák or Kossuth). Since the specimens were not collected in situ, although this does not influence the character of the material, a collecting bias cannot be completely excluded. However, the fact that all plant fossils have been collected by the same person (MB), excludes a difference in collecting method between the different plant sites. The collection of plant fossils is deposited in the Botanical Department of the Hungarian Natural History Museum in Budapest and labelled with inventory numbers preceded by prefix BP. Since the fern material was preserved without cuticles, the macroscopic features were studied using an Olympus SZX9 stereo microscope. Pictures were taken with a Nikon 800E, objective Nikkor $60 \mathrm{~mm}$ micro, in double polarized light.

Fern taxonomy, intraspecific variability and plant cooccurrence were studied. For the latter, a database was constructed showing all co-occurrences between fern remains and other plant fossils on the same rock slabs. These provide important insights into taxa co-occurring within the same habitats, since the plant assemblage can be considered (par-) autochthonous. Coniopteris sp. is the only taxon missing in the statistical analyses because it is represented by three specimens only.

Co-occurences were studied with statistical methods. Data were collected from both sides of the slabs and they were treated separately. In some cases, the state of 


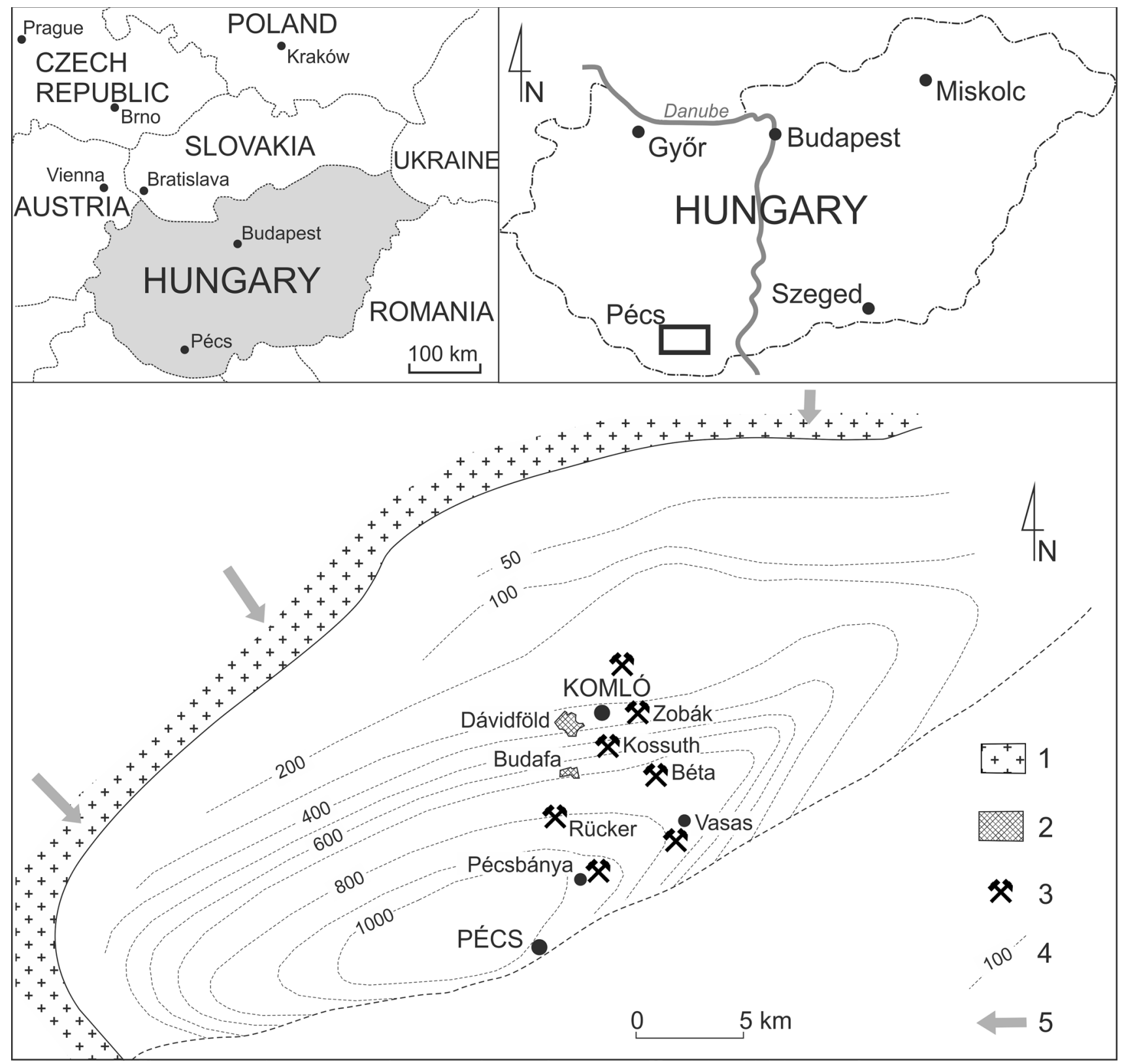

Fig. 1 Map of the localities and sedimentary basin in the Mecsek Mts., Hungary. 1 Granitoid denudated area (sedimentary basin margine), 2 Dumps, 3 Coal mines, 4 Isolines of hypothetical basin thickness, $\mathbf{5}$ direction of granitoid clast transport

preservation and fragmentation of the remains was too poor for a specific determination; in this case, the data were considered at a generic level. The database comprehends a total of 903 records ( $\mathrm{S} 1$ - the complete database is given in the supplement to this paper). For the statistical and mathematical analyses the programs $\mathrm{R}$ (R Core Team 2011) and PAST (Hammer et al. 2001) were used. The data were appropriate for an integration of cluster analysis and ordination that is suggested to be applied to the same data for palaeoecological purposes (Shi 1993).
Multivariate analytical methods were used to analyse the data, a hierarchical grouping and an ordination to detect the background affecting factors.

The purpose of the cluster analysis used in this study is to discover the system of organization of groups in which the members share common properties (Kovács et al. 2012).

The advantage of Ward's method is that it minimizes the total within-cluster variance. It is widespread used in 

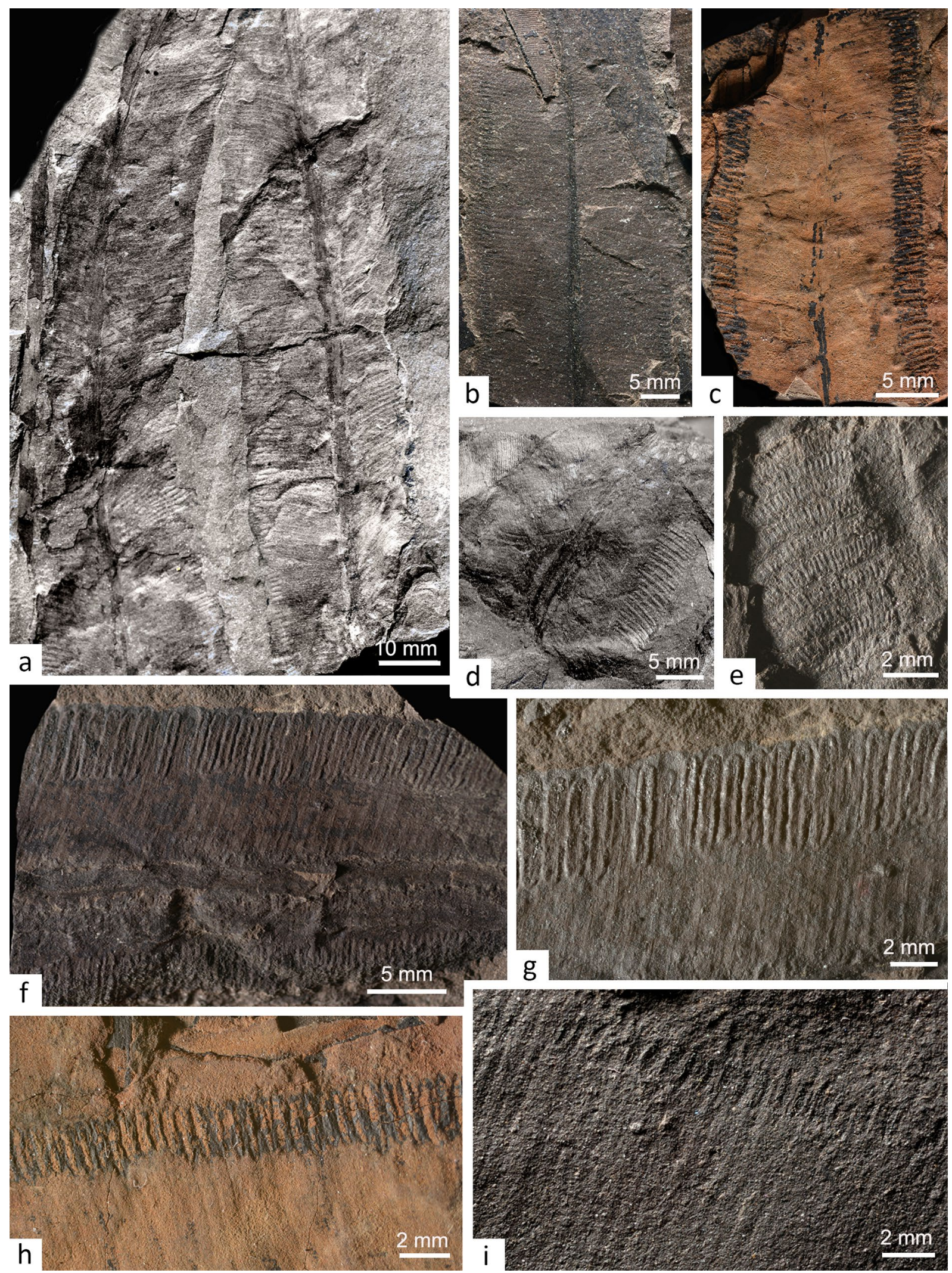
४Fig. 2 Marattiopsis hoerensis (Schimper) Thomas 1913. a Two typical sterile pinnules, with distinct venation, No. 92.262.1; b Detail of fertile pinnule with short synangia (immature?) No. 96.334.1. (photo MS); c Detail of fertile pinnule with short synangia (old?) No. 2017.53.1. (photo MS); d Base of a fertile pinnule, No. 98.496.1; e Synangia under high magnification showing sporangia, No. 96.72.1. (photo MS); f Detail of fertile pinnule with fully developed synangia, No. 94.551.1. (photo MS); $\mathbf{g}$ Detail of $\mathbf{f}$ showing the arrangement and dimension of the synangia (photo MS); $\mathbf{h}$ Detail of $\mathbf{c}$ showing the arrangement and dimension of the synangia (photo MS); $\mathbf{i}$ Detail of $\mathbf{b}$ showing the arrangement and dimension of the synangia (photo MS)

paleontology and in palaeoecology (Chabrerie et al. 2003; Currano et al. 2010; Teodoridis et al. 2011; Barbacka et al. 2014).

Principal component analysis (PCA) was conducted on the variance-covariance matrix for detecting the background factors influencing the vegetation groups. The joint distribution of the species along the orthogonal axes of PCA analysis may give a rough estimation of their ecological profiles. This method is commonly used in palaeobotany since Spicer and Hill used it in 1979 (Spicer and Hill 1979) and gave a good results in the palaeoecological analysis of Jurassic flora from Mecsek (Barbacka et al. 2016). The effectiveness depends on the original correlation values among the variables. If many variables are correlated, the first component would explain a high percentage of variance (Barbacka et al. 2014; Kovács et al. 2012). The number of principal components is less than or equal to the number of original variables (see also Supplement, S3).

\section{Systematic palaeontology}

Order Marattiales Link 1833

Family Marattiaceae Kaulf 1824

Genus Marattiopsis Schimper 1869

Marattiopsis hoerensis (Schimper) Thomas 1913

Figure $2 \mathrm{a}-\mathrm{i}$

Selected synonyms.

1869 Angiopteridium hoerense-Schimper: p. 604, pl. 38, fig. 7.

? 1869 Angiopteridium muensteri (Göppert)—Schimper: p. 603, pl. 35, figs. 1-6.

1913 Marattiopsis hoerensis (Schimper)—Thomas: p. 229.

?1913 Marattiopsis anglica-Thomas: p. 228, pl. 23, figs. $1-3$, text-fig. 1 .
1919 Marattiopsis hoerensis (Schimper) ThomasAntevs: p. 21, pl. 2, figs. 2-13, pl. 6, fig. 40.

1924 Marattiopsis hoerensis (Schimper) ThomasChow: p. 5, pl. 2, figs. 2-3.

1931 Marattiopsis hoerensis (Schimper) ThomasHarris: p. 60, pl. 13, figs. 2, 3, 5, 6, 9-11, 15, 16, text-figs. 21-22.

?1961 Marattia anglica (Thomas)-Harris: p. 72, text-fig. 23.

?1974 Marattiopsis muensteri (Göppert)—Schimper: p. 514.

2002 Marattiopsis hoerensis (Schimper) Thomas-Van Konijnenburg-van Cittert: p. 115.

2011 Marattia hoerense (Schimper) Harris-Kiritchkova and Nosova: p. 51, pl. 9, fig. 10, pl. 11, figs. 1-2.

Description. The fronds are pinnate with linear pinnae (15-40 mm wide) decreasing in size towards the apex. No entire pinna is preserved; the longest fragment reaches $180 \mathrm{~mm}$ in length. The base of the pinnae is slightly expanded (Fig. 2d), nearly cordate, the margins are entire; no pinna apex is preserved. The midrib is $1-7 \mathrm{~mm}$, most frequently $4 \mathrm{~mm}$, wide. Lateral veins are generally poorly visible, parallel, sometimes forking once at the midrib, and reaching the margins at almost right angle. The number of veins varies (9-17 per $10 \mathrm{~mm}$, in most cases $10-12$ per $10 \mathrm{~mm}$ ). Synangia are $2-10 \mathrm{~mm}$ long and arranged perpendicularly to the pinna margin; their number corresponds to the number of lateral veins. The pinnae width/synangia length ratio ranges from 5 to $29 \%$. Synangia may be of two types. Synangia type 1 are elongated with rounded ends, about $0.8 \mathrm{~mm}$ wide with neighbouring synangia touching each other; a central double line indicates the slit (Fig. 2f, g). Synangia type 2 are spindle shaped with rather acute ends and a width of about $0.5 \mathrm{~mm}$; they do not touch and the central line is not recognizable (Fig. 2h, i). The number of sporangia is not clear in both synangia types (Fig. 2e).

Remarks. The genus Marattiopsis has been created by Schimper (1869) for extinct taxa resembling species of the extant genus Marattia O. Swartz 1788 (e.g., Bomfleur et al. 2013; Escapa et al. 2015). The pinna width to synangia length ratio (PW/SL), venation pattern and morphology of the pinna base are considered the most important features for the distinction between different species within Marattiopsis (e.g., Harris 1931, 1961; Kvaček 2014; Escapa et al. 2015), especially morphologically close species such as $M$. hoerensis (Schimper) Thomas 1913, M. muensteri (Göppert) Schimper 1874, and M. anglica Thomas 1913, M. asiatica Kawasaki 1939, M. crenulata Lundblad 1950 and $M$. angustifolia.

The frond fragments from the Jurassic of Hungary are mostly preserved as central pinnae fragments with only one 


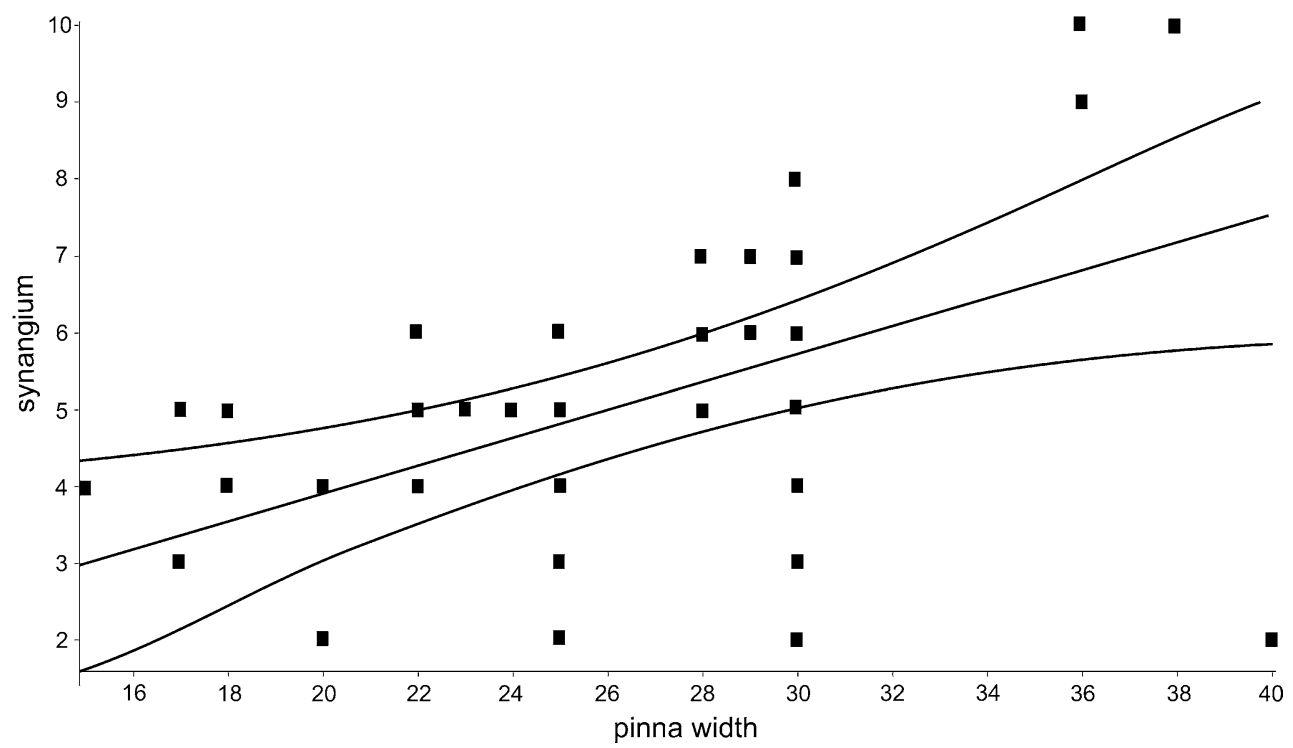

Fig. 3 Linear regression of leaf width/synangia length ratio in the Hungarian Marattiopsis hoerensis (Schimper) Thomas 1913 specimens

basal frond fragment. The pinnae fragments can be distinguished based on their synangia shape and dimension in two groups (ST1 and ST2), despite having the same venation pattern and pinna size. The PW/SL ratio, calculated for all well enough preserved specimens (about $70 \%$ of the frond fragments), show a continuous data set between the lowest and highest values (5-29\%; Figs. 3, S2). There is no significant difference between both groups of pinnae (ST1 and ST2). They tend a little to association of wider pinnae with longer synangia, but not strongly. The extreme values also are still within the curve limit. Since the pinnae are often fragmentarily preserved and features such as the shape of the base or of the entire pinna are lacking, the PW/SL ratio is considered as a convenient and easily available character for taxonomical classification. However, the variability observed in the rich Hungarian material casts some doubts on the usefulness of this criterion for specific determinations.

Moreover, different stages in the synangia development of extant Marattiaceae (Senterre et al. 2014) correspond to different synangia types observed in M. hoerensis from Hungary. Small oval or slightly elongated immature synangia on extant fronds have a similar PW/SL ratio as fossil specimens with ST1. Mature synangia are much longer and wider, whereas old ones decrease in size and become spindle-shaped, but do not show any median slit, similar to ST2. This highly suggests that the observed differences in PW/SL ratio correspond to different stages of synangia development. Antevs (1919) described similar differences in synangia type, with mature long synangia (Antevs 1919, pl. 2, fig. 3) and young short synangia (Antevs 1919, pl. 2, fig. 4a) from the Late Triassic-Early Jurassic flora of Sweden.
Marattiopsis hoerensis differs from other species because of its PW/SL ratio, the expanded, cordate base, the basal veins turning backward and the reducing pinna size from the base to the apex. These features, apart from the basal veins, which are not visible, allow us to classify the Hungarian specimens as M. hoerensis. However, if the PW/SL ratio is linked to the developmental stages of the synangia as suggested above, then the differences between M. hoerensis and other similar species (Harris 1931, 1961) are reduced to mere details. In that case, $M$. muensteri differs because of its rounded, but not expanded base, $M$. crenulata because of its crenulate margin and $M$. asiatica because of the higher density of veins forking in the lamina. Kilpper (1964), proposed to fuse $M$. hoerensis, M. muensteri, M. anglica, M. crenulata into one species, Marattiopsis intermedia (Münster) Kilpper, 1964, arguing that there is an overlap between all these species. Van Konijnenburg-van Cittert (1975, p. 209, tab. 1) agreed that the species were rather alike, but considered the overlap a result of comparing small distal pinnules from one species with large proximal ones of another species, even admitting that in some floras there might exist frond fragments with intermediate pinnae.

Comparing pinnae shape and their bases in some extant marattialeans (e.g., Marattia fraxinea J. Sm. ex Gmel. 1924, M. sorbifolia Swartz 1806, M. laxa Kunze 1844), these seem to vary along the rachis. Bases in pinnae are more strongly asymmetric at the top and become more symmetric towards the basis of the frond; the lowermost may be plain or lobed. Such a high variability within single herbarium specimens could indicate that some of the differences in shape may be caused by environmental conditions or plain variability. Thus, it cannot be excluded that the four species discussed 
by Harris (1931), M. hoerensis, M. asiatica, M. crenulata and $M$. angustifolia, are conspecific, as suggested by Kilpper (1964).

The in situ spores of M. hoerensis are known as monolete and oval to bean-shaped, about $28 \mu \mathrm{m}$ long, with a thick and finely granulate wall (Harris 1931; Lundblad 1950; Van Konijnenburg-van Cittert 1975). These belong to the dispersed spore genus Punctatosporites Ibrahim 1933. Few in situ spores were trilete (less than 1\%) with long laesurae (Van Konijnenburg-van Cittert 1975), corresponding to the dispersed genus Granulatisporites Ibrahim, 1933. However, Götz et al. (2011, tab. 2) did not identify these two genera among the dispersed spores of the Upper Triassic-Lower Jurassic sediments of Hungary. M. hoerensis was distributed from the Rhaetian to Lower Jurassic in Europe (Table 1).

Material. The species is represented by fertile pinnae fragments; only few specimens are preserved as well. BP 89.157.1, 94.433.1, 94.551.1, 96.52.1, 96.57.1-58.1, 96.67.1-74.1, 96.76.1, 96. 78.1, 96.172.1, 96.262.1, 96.325.1, 96.334.1, 96.480.1-482.1, 98.356.1-359.1, 98.426.1, 98.470.1, 98.513.1-520.1, 2006.661.1-665.1, 2007.139.1, 2007.806.1, 2007.910.1 (46 specimens)

\section{Order Osmundales Link 1833}

Family Osmundaceae Martinov 1920

Remarks. The Hungarian Jurassic species of Todites and Cladophlebis were extensively described and discussed in Barbacka and Bodor (2008). Here we provide the same descriptions supplemented by brief remarks in order to give a complete overview on all fern taxa from the locality. Todites is a fossil genus for fertile osmundaceous fronds, Cladophlebis for sterile fronds of which fertile units often belong to the osmundaceous genera Todites or Osmundopsis (Harris 1961; Van Konijnenburg-van Cittert 1996). However, this distinction is not strictly followed, since Cladophlebis species with sporangia have been described (Nathorst 1878; Watson 1969), as well as Todites species without sporangia (Seward 1911; Oishi 1939-1940; Kräusel 1958; Van Konijnenburg-van Cittert and Van der Burgh 1989). Harris (1961) suggested close relationships between both genera within the family Osmundaceae, a consideration we follow for our Cladophlebis and Todites species of the Jurassic of Hungary (Barbacka and Bodor 2008).

\section{Genus Todites Seward 1900}

Todites princeps (Presl in von Sternberg) Gothan 1914 Figure $4 \mathrm{a}$

Selected synonyms (for more details see Schenk 1867; Harris 1931, 1961; Schweitzer 1978; Barbacka and Bodor 2008).
1838 Sphenopteris princeps -Presl in von Sternberg: $\mathrm{p}$. 126, pl. 59, figs. 12-13.

1867 Acrostichites princeps Presl-Schenk: p. 46-49, pl. 7, figs. 3-5, pl. 8, figs. 1, 1a.

1931 Todites princeps (Presl) Gothan-Harris: p. 35-39, pl. 11, figs. 1, 2, 4, 9, pl. 12, fig. 3, text-figs. 8-9.

1961 Todites princeps (Presl) Gothan-Harris: p. 93-99, text-figs. 30-31.

1978 Todites princeps (Presl) Gothan-Schweitzer: $\mathrm{p}$. $31-36$, pl. 1, figs. $3-5$, pl. 2, figs. 1-6, pl. 3, figs. $1-7$, text-figs. $10-18$.

2008 Todites princeps (Presl) Gothan-Barbacka and Bodor: p. 134, pl. 1, figs. 1-5.

2008 Todites princeps (Presl) Gothan-Bodor and Barbacka: p. 212.

Description (after Barbacka and Bodor 2008; Bodor and Barbacka 2008). Fronds are bipinnate in an anadromic way, with similar sterile and fertile fronds. The rachis is 1.5 $4.5 \mathrm{~mm}$ wide and smooth. Pinnae reach more than $60 \mathrm{~mm}$ in length (no complete pinnae are preserved). The rachis of the pinnae is $0.5-0.8 \mathrm{~mm}$ wide. Pinnules are attached alternately or oppositely, arising from the rachis at about $90^{\circ}$ (with their angle decreasing slightly towards the top of the pinna). Pinnules are variable in shape and size, margins are mostly entire to crenate to deeply lobed. They are $4-10 \mathrm{~mm}$ long and $2-4 \mathrm{~mm}$ wide. Their apex is usually rounded. Circular sporangia are attached densely on the lower surface of the pinnules.

Remarks. The pinnule size and shape vary noticeably in this species depending on the position of the pinnae on the fronds (Harris 1931, 1961; Barbacka and Bodor 2008; Bodor and Barbacka 2008). In the Hungarian material in situ spores could not be extracted; however, they are well known from the Jurassic of Yorkshire (Harris 1961). The spores are supposed to be roundish (20-40 $\mu \mathrm{m}$ diameter) with a smooth wall and a distinct trilete mark that is smaller than the radius of the spores. This spore type belongs to the dispersed spore genus Todisporites Couper 1958, represented in the Upper Triassic-Lower Jurassic sediments of Hungary by Todisporites major Couper 1958 and T. minor Couper 1958 (Götz et al. 2011). The latter might represent the in situ spores of T. princeps.

Material. BP 94.187.1, 94.190.1, 94.192.1, 94.194.1, 94.485.1-486.1, 94.690.1-692.1, 94.710.1-711.1, 2008.421.1-423.1 (44 specimens).

Todites goeppertianus (Münster in Göppert) Krasser 1922 Figure $4 b$ 

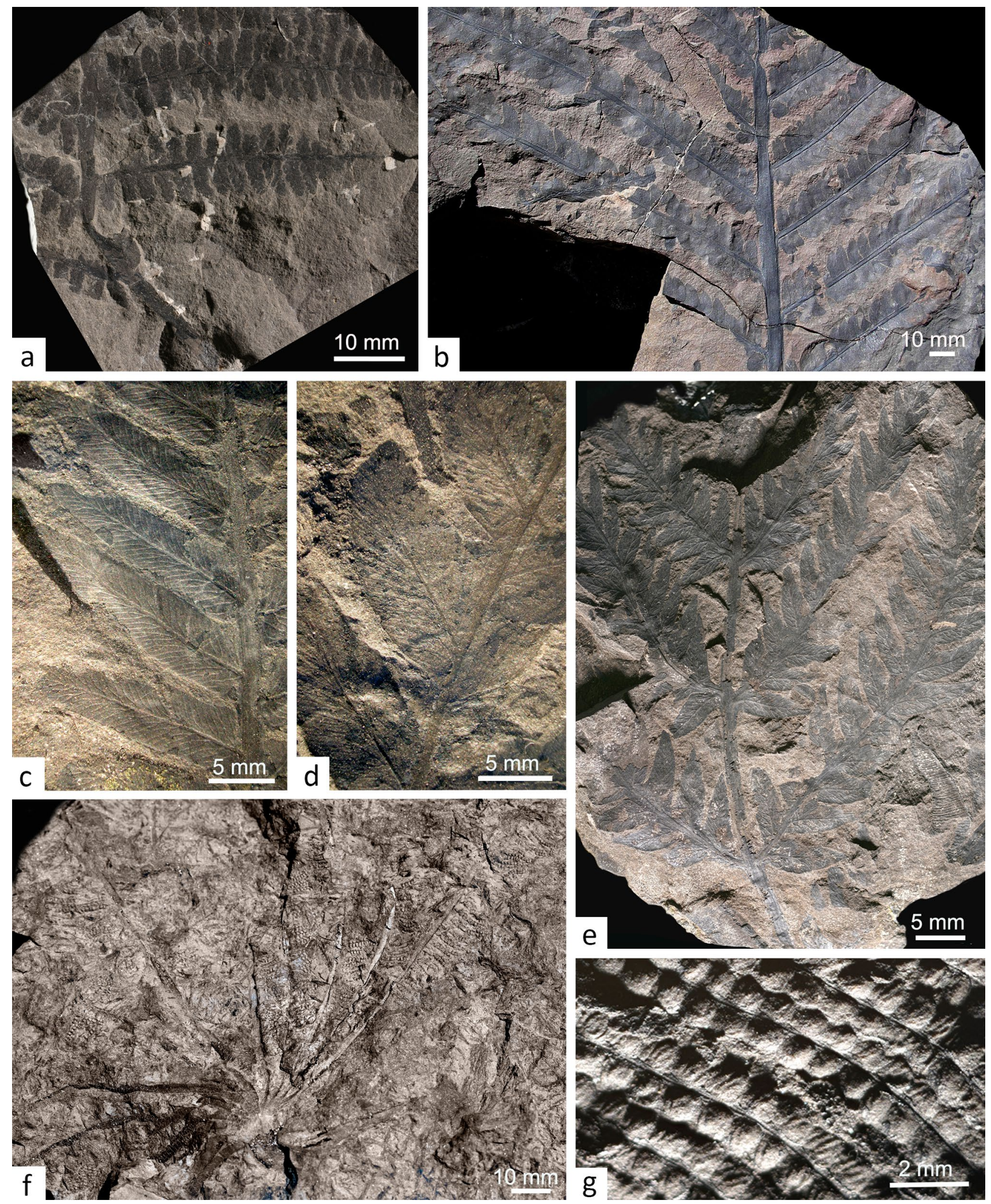
4Fig. 4 Ferns of the Early Jurassic of Hungary. a Frond fragment of Todites princeps (Presl in von Sternberg) Gothan 1914, No. 94.692.1. (photo MS); b Frond fragment of Todites goeppertianus (Münster in Göppert) Krasser 1922, No. 89.224.1; c Pinna fragment of Cladophlebis denticulata (Brongniart) Fontaine, 1899, No. 2004.1040.1; d Pinna fragment of Cladophlebis haiburnensis (Lindley and Hutton) Brongniart 1849, No. 89.194.1; e Frond fragment of Cladophlebis roessertii (Presl in von Sternberg) Saporta 1873, No. 2004.968.1. (photo MS); f Basal frond fragment of Phlebopteris angustiloba (Presl in von Sternberg) Hirmer and Hörhammer 1936, No. 89.440.1. (photo MS); g Venation pattern of Phlebopteris angustiloba (Presl in von Sternberg) Hirmer and Hörhammer 1936, No. 94.474.1. (photo MS)

Selected synonyms (for more details see Schenk 1867; Harris 1931; Barbacka and Bodor 2008).

1846 Neuropteris goeppertiana-Münster in Göppert: p. 104, pl. 8, 9, figs. 8-10.

1867 Acrostichites goeppertianus-Schenk: p. 44-46, pl. 5, figs. 5, 5a.

1922 Todites goeppertiana (Münster) KrystofovitschKrasser: p. 355.

1931 Todites princeps (Presl) Gothan-Harris: p. 31-35, pl. 11, figs. 3, 8, text-fig. 7 .

2008 Todites goeppertianus Krasser-Barbacka and Bodor: p. 134-135, pl. 1, figs. 6-9, pl. 2, figs. 1-4.

2008 Todites goeppertianus Krasser-Bodor and Barbacka: p. 212, figs. 26A-J.

Description (after Barbacka and Bodor 2008). Fronds are bipinnate and large with sterile and fertile leaves representing different morphotypes. The sterile morphotype has a smooth primary rachis $(<20 \mathrm{~mm})$ from which arise the pinnae at about $45^{\circ}$. Pinnules are inserted oppositely, close to each other, but not overlapping the pinna rachises (1.5-3.0 mm wide). They are linear to falciform, 5-10 mm long and 2.5-6.0 mm wide. The bases are broad, sometimes acroscopically slightly extended, and usually touching the neighboring pinnules. The margins are entire, the apex subacute to rounded. Venation is of neuropterid-type, secondary veins fork once. Fertile fronds are large with a $20 \mathrm{~mm}$ wide primary rachis and an up to $3 \mathrm{~mm}$ wide pinna rachis. Pinnules are often falciform, 5-8 mm long and 3.0-4.5 mm wide, not touching the neighboring pinnules. The margins are entire with a rounded apex, the venation is of neuropterid-type. Sporangia cover the entire lower side of the pinnules; they are globose and about $0.25-0.3 \mathrm{~mm}$ in diameter. In situ spores are trilete, about $40 \mu$ in diameter.

Remarks. This species differs from other species from this genus due to its characteristic neuropterid venation (pecopterid venation in the other taxa; Barbacka and Bodor 2008). For a more detailed discussion see Barbacka and Bodor
(2008). Krasser (1922, p. 355) indicated „Krystof.” as author of the combination "Todites goeppertiana" without giving any references to the paper of Krystofovich. However, later most authors referred this combination to Krasser (1922).

Material. BP 60.150.1, 89.179.1, 89.254.1-264.1, 89.266.1, 89.448.1, 89.452.1, 89.457.1, 94.188.1, 94.210.1, 94.222.1, 94.226.1-227.1, 94.437.1, 94.440.1, 94.444.1, 94.489.1, 94.517.1, 94.616.1-631.1, 94.633.1-635.1, 94.728.1, 94.798.1, 96.127.1, 96.137.1R, 96.338.1, 96.341.1, 98.351.1, 96.384.1, 96.386.1, 98.763.1, 98.1003.1, 2000.1168.1, 2004.1182.1, 2005.644.1, 2006.663.1R, 2006.681.1-682.1, 2007.155.1, 2007.175.1, 2009.465.1 (55 specimens).

Genus Cladophlebis Brongniart 1849

Cladophlebis denticulata (Brongniart) Fontaine 1899

Figure 4c

Selected synonyms (for more details see Harris 1961; Barbacka and Bodor 2008).

1828a Pecopteris denticulata Brongniart-Brongniart:, p. 57 (nomen nudum).

1828a Pecopteris denticulata Brongniart-Brongniart: $\mathrm{p}$. 301, pl. 98, figs. 1-2.

1899 Cladophlebis denticulata Brongniart-Fontaine: $\mathrm{p}$. 71, pl. 4, fig. 2, pl. 7, fig. 7.

1931 Todites denticulatus (Brongniart) Krasser-Harris: p. 48, pl. 9, figs. 9-10.

1961 Todites denticulatus (Brongniart) Krasser/Cladophlebis denticulata (Brongniart) Fontaine-Harris: p. 79-87, text-figs. 25-27.

1961 Phlebopteris braunii (Göppert) Hirmer et Hörhammer-Nagy: p. 618, pl. 9, fig. 3.

1997 Cladophlebis denticulata ((Brongniart) FontainePopa: fig. 30.

2002 Cladophlebis denticulata (Brongniart) Fontainevan Konijnenburg-van Cittert: p. 115, pl. 1, fig. 3.

2008 Cladophlebis denticulata (Brongniart) FontaineBarbacka and Bodor: p. 135-138, pl. 2, figs. 5-9.

2008 Cladophlebis denticulata (Brongniart) FontaineBodor and Barbacka: p. 212, figs. 25A-G.

Description (after Barbacka and Bodor 2008). Fronds are bipinnate with a ridged or smooth rachis of 1-4 mm width. Pinnae are attached oppositely, alternately or subalternately with an angle of $27^{\circ}-65^{\circ}$ that decreases slightly towards the top of the frond. Pinnules arise oppositely, semi-alternately or alternately. They are elongated (length/width ratio $=1.5-4.6$ ), often falcate, 7-28 $\mathrm{mm}$ long and 3-9 mm wide. The margin of the pinnules is generally dentate, but 
partly dentate or entire margins are not rare. The apex is acute or subacute, its base as wide as the pinnules or slightly extended acroscopically. The veins are distinct; the midrib reaches the apex of the pinnule; secondary veins divide once or twice, often only in the basal part of pinnules. The number of secondary veins on each half pinnule varies from 4 to 14 , the vein density at the margin is $3-9 / \mathrm{cm}$.

Remarks. Harris (1961) suggested to use the name T. denticulatus (Brongniart) Krasser 1922 for fertile fronds and C. denticulata for sterile frond fragments and van Konijnenburg-van Cittert (1996) has demonstrated that the sterile fronds can actually belong to two different fertile taxa, respectively $T$. denticulatus and Osmundopsis sturii depending on the morphology of their fertile parts. Since our specimens are all sterile we use in this study the name $C$. denticulata. C. denticulata is easily distinguished from the other Cladophlebis species of Hungary due to its elongate pinnules with dentate margin, (sub)acute apex and ridged rachis (for a detailed discussion see Barbacka and Bodor 2008). The species is characterized by a high variability in shape and dimension of the pinnules that has been related to environmental adaptations (Barbacka and Bodor 2008; Bodor and Barbacka 2008). The specimen described by Nagy (1961) as P. braunii belongs to C. denticulata.

The macroremains of this species were found from the Late Triassic to the Cretaceous (Bodor and Barbacka 2012) of the entire world (Tab. 1). The in situ spores of T. denticulatus are roundish (25-48 $\mu \mathrm{m}$ diameter) with a thin, punctate wall and a delicate trilete aperture that extends over the entire radius (Harris 1961). This spore type belongs to the dispersed spore genus Punctatisporites Ibrahim 1933. The latter has not been mentioned so far from the palynological record of the Upper Triassic (Rhaetian) and Lower Jurassic (Hettangian) Mecsek Coal Formation (Götz et al. 2011).

Material. BP 91.113.1, 94.6.1, 94.35.1, 94.213.1, 94.435.1, 94.438.1, 94.438.1R, 94.450.1, 94.552.1, 94.704.1, 96.75.1, 96.123.1-125.1, 96.125.1R, 96.127.1-129.1, 96.317.1, 96.333.1,widespread species in the Jurassic 96.339.1, 96.350.1, 96.389.1, 96.390.1, 96.395.1, 96.397.1, 96.403.1, 96.504.1, 98.4.1, 98.1050.1-1051.1, 98.1074.1, 98.1177.1, 98.340.1, 2002.5.1, 2002.18.1, 2002.134.1, 2002.1004.11007.1, 2004.1001.1, 2004.1003.1-1011.1, 2004.1015.1, 2004.1021.1, 2004.1109.1, 2004.1183.1, 2004.1200.1, 2004.966.1, 2004.967.1, 2004.969.1-973.1, 2004.977.1979.1, 2004.982.1, 2004.983.1, 2004.986.1, 2004.986.1R, 2004.988.1, 2004.991.1, 2004.995.1, 2004.999.1, 2005.830.1, 2005.840.1-844.1, 2005.863.1, 2006.683.1 (75 specimens).
Cladophlebis haiburnensis (Lindley and Hutton) Brongniart 1849

Figure 4d

Selected synonyms (for more details see Harris 1961; Barbacka and Bodor 2008).

1836 Pecopteris haiburnensis-Lindley et Hutton: p. 97, pl. 187.

1849 Cladophlebis haiburnensis (Lindley et Hutton)Brongniart, p. 105.

1997 Cladophlebis haiburnensis (Lindley et Hutton) Brongniart-Popa: fig. 25.

1997 Cladophlebis haiburnensis (Lindley et Hutton) Brongniart-Barbacka and Bodor: p. 138-139, pl. 2, figs. 10-13.

1997 Cladophlebis haiburnensis (Lindley et Hutton) Brongniart-Bodor and Barbacka: p. 212, figs. $25 \mathrm{H}-\mathrm{L}$.

Description (after Barbacka and Bodor 2008). The frond is bipinnate with a slender main rachis that is up to $2.5 \mathrm{~mm}$ wide, and smooth. The primary rachises are oppositely inserted and about $1.0-1.5 \mathrm{~mm}$ wide. Pinnules arise alternately or oppositely, 6-18 $\mathrm{mm}$ long and 3-8 $\mathrm{mm}$ wide (max. $25 \times 10 \mathrm{~mm}$ ). They are lanceolate (length/width ratio $2-3$ ), straight or falcate, depending on its position along the frond, with an entire margin and a subacute apex. Pinnules are attached to the rachis with the entire basis, which may be acroscopically extended. Adjacent pinnules touch each other or are divided by an interval of about $1 \mathrm{~mm}$. Venation is of pecopterid type, with straight midvein and secondary veins forked once or twice. The number of veins on half of the pinnule is $4-11$, vein density ranges from 7 to 28 veins $/ \mathrm{cm}$; the arising angle of the secondary veins is $16^{\circ}-64^{\circ}$.

Remarks. Cladophlebis haiburnensis is one of the most widespread species in the Jurassic (e.g., Barbacka and Bodor 2008; Bodor and Barbacka 2012), It resembles C. denticulata due to its high variability in morphology (pinnules size, number of secondary veins) nonetheless both species are well distinguished from each other (Barbacka and Bodor 2008).

Material. BP 89.4.1, 89.186.1, 89.346.1, 94.223.1, 94.229.1, 94.436.1, 94.436.1R, 94.637.1, 94.720.1, 96.337.1, 96.345.1-346.1, 96.385.1, 96.391.1, 96.409.1, 98.1073.1, 98.762.1, 2001.625.1, 2004.975.1-976.1, 2004.980.1, 2004.989.1, 2004.990.1, 2004.1017.1 (24 specimens).

Cladophlebis roessertii (Presl in von Sternberg) Saporta 1873

Figure 4e 
Selected synonyms (for more details see Schenk 1867; Gothan 1914; Barbacka and Bodor 2008).

1838 Alethopteris roessertii-Presl: p. 145, pl. 33, figs. 14a, b.

1867 Asplenites roessertii Presl in von SternbergSchenk: p. 49-53, pl. 7, figs. 6-7, 7a, pl. 10, figs. $1-4$.

1873 Cladophlebis roessertii (Schenk)-Saporta: p. 301, pl. 31, fig. 4.

1926 Cladophlebis roessertii (Schenk non Pres1) Saporta-Harris: p. 57-59, text-figs. 3A-D.

2008 Cladophlebis roessertii (Schenk) Saporta-Barbacka and Bodor: p. 138-139, pl. 2, figs. 10-13.

2008 Cladophlebis roessertii (Schenk) Saporta-Bodor and Barbacka: p. 212, figs. 25H-L.

Description (after Barbacka and Bodor 2008). Fronds are slender and probably bipinnate, the fragments are up to $55 \mathrm{~mm}$ long. The main rachis is $1.5 \mathrm{~mm}$ wide, the pinna rachis $0.5-0.8 \mathrm{~mm}$ wide. Pinnae are inserted oppositely with a distance between neighboring pinnae of $15 \mathrm{~mm}$. Pinnules are inserted oppositely; they are triangular with an acute apex and a relatively wide base, or rarely rectangular with a rounded apex; near the apex are the pinnules falcate. The adjacent bases touch each other. The pinnules are up to $18 \times 6 \mathrm{~mm}$ (at the base of the pinna), but generally 6-7 $\times 3-4 \mathrm{~mm}$. The venation is of pecopterid type, secondary veins are forked mostly once, occasionally twice. The number of veins at the margin of pinnule is usually $5-11$, vein density is $8-13$ veins $/ \mathrm{cm}$.

Remarks. There seems to be some confusion on the authorship of this taxon. Although Schenk (1867) clearly states that he considers his material belonging to the same species as Presl in von Sternberg (1820-1838, p. 145), later authors, including Harris (1926), base their identification on Schenk's paper (1867), pointing out that Presl's specimen is indeterminable and differs from Schenk's material, and thus, use Schenk as official author of the taxon (followed also by Barbacka and Bodor 2008). Since Presl in von Sternberg (1820-1838) is, however, the first to use of the name, Schenk's name would be a later homonym, if he did not expressly refer to Presl's species. Thus the correct first author is Presl in von Sternberg (1820-1838). Saporta (1873) moved the species to Cladophlebis, while Gothan (1914) ascribed it to Todites, indicating, however, that Krystofovich (1912) had already proposed the new combination. Since we do not have any fertile material in Hungary, we use the sterile version Cladophlebis following Harris (1961). The species is well represented in the Late Triassic to Cretaceous around the globe (Table 1).
Material. BP 2004.19.1, 2004.968.1, 2004.974.1, 2004.981.1, 2004.984.1-985.1, 2004.987.1, 2004.990.1, 2004.992.1-998.1, 2005.839.1, 2004.1000.1, 2004.1014.1, 2004.1017.1R, 2004.1018.1-1020.1 (22 specimens)

Order Gleicheniales Schimper 1869

Family Matoniaceae Presl 1847

Genus Phlebopteris Brongniart 1836

Phlebopteris angustiloba (Presl in von Sternberg) Hirmer and Hörhammer 1936

Figures 4f, g, 5a, b

Selected synonyms (for more details see Schenk 1867; Harris 1931).

1838 Gutbiera angustiloba-Presl in von Sternberg: p. 116, pl. 33, figs. 13a-e.

1843 Andriana baruthina-Braun: p. 42, pl. 3-4, 6, 12, pl. 10, figs. 1-3.

1867 Gutbiera angustiloba Presl-Schenk: p. 64, pl. 18, figs. 5-10.

1867 Andriana baruthina Braun-Schenk: p. 87-89, pl. 21, figs. 1-7, pl. 22, fig. 1.

1867 Andriania baruthina Braun-Schenk: p. 87, pl. 21, figs. 1-6.

1891 Laccopteris angustiloba Presl-Raciborski: p. 15, pl. 2, figs. 6-9.

1892 Laccopteris angustiloba Presl-Raciborski: pl. 2, fig. 22.

1914 Gutbiera angustiloba Presl-Gothan: p. 99-100, pl. 17 , fig. 5 .

1914 Andriana baruthina Braun-Gothan: p. 102, pl. 17, fig. 8, pl. 18, figs. 1-2.

1914 Andriana norimbergica-Gothan: p. 102-103, pl. 17, figs. 6-7.

1922 Andriania baruthina Braun-Krasser: p. 348.

1931 Laccopteris angustiloba (Presl) Raciborski-Harris: p. 74-77, pl. 14, figs. 6-17, text-fig. 26.

1936 Phlebopteris angustiloba (Presl)-Hirmer and Hörhammer: p. 26, pl. 6, text-fig. 5.3.

1950 Phlebopteris angustiloba (Presl) Hirmer et Hörhammer-Lundblad: p. 23-24, pl. 2, fig. 14; pl. 3, figs. $1-5$, pl. 13, fig. 2 , text-fig. 4.

?1998 Aninopteris formosa-Givulescu et Popa: p. 52, pls. 1, 2, text-figs. 1-6.

1993 Phlebopteris angustiloba (Presl) Hirmer et Hörhammer-Van Konijnenburg-van Cittert: p. 24143, pl. 1, figs. 2, 5 .

1997 Phlebopteris angustiloba (Presl) Hirmer et Hörhammer-Popa: fig. 13. 


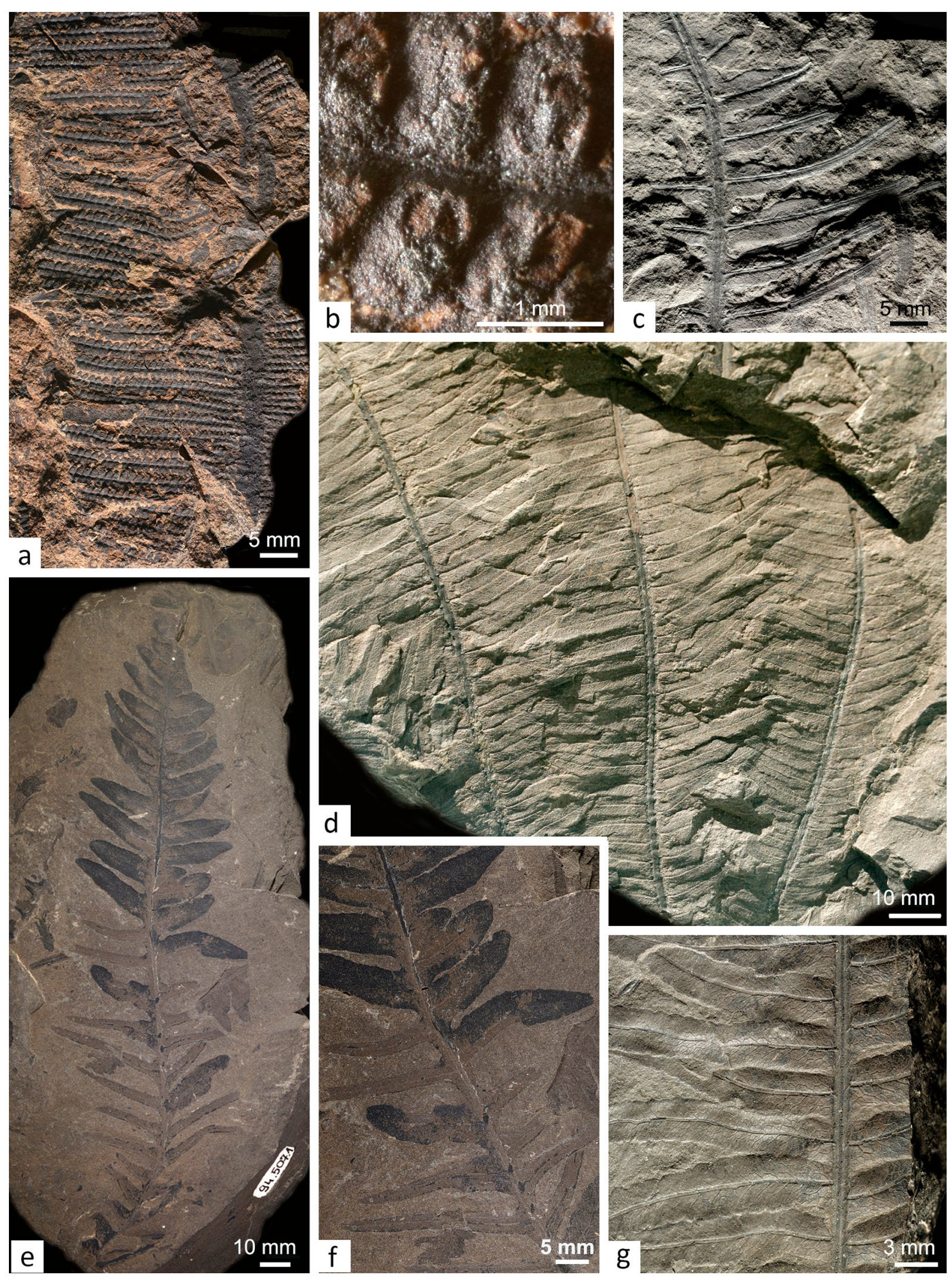


4Fig. 5 Ferns of the Early Jurassic of Hungary. a Phlebopteris angustiloba (Presl in von Sternberg) Hirmer and Hörhammer 1936, pinna fragment, No. 89.485.1. (photo MS); b Detail of a with impressions of the sori (photo MS); c Pinnae with partly sterile and partly fertile pinnules of Phlebopteris kirchneri Barbacka and Kustatscher sp. nov., No. 2003.453.1. (photo MS); d Sterile frond fragment of Phlebopteris kirchneri Barbacka and Kustatscher sp. nov., holotype, No. 96.266.1.; e Pinnae with sterile and fertile pinnules of Phlebopteris kirchneri Barbacka and Kustatscher sp. nov., No. 94.507.1. (photo MS); f Detail of e of Phlebopteris kirchneri Barbacka and Kustatscher sp. nov.; g Pinnae fragment with clear details of the pinnae attachment and venation pattern of Phlebopteris kirchneri Barbacka and Kustatscher sp. nov., No. 94.291.1. (photo MS)

2002 Phlebopteris angustiloba (Presl) Hirmer et Hörhammer-Van Konijnenburg-van Cittert: p. 115, 119.

? 2002 Phlebopteris muensteri (Schenk) Hirmer et Hörhammer-Van Konijnenburg-van Cittert: p. 115.

Description. Fertile and sterile fronds are similar in gross morphology, palmately compound and slender. About 12 pinnae arise from the base, a petiole is not preserved (Fig. 4f). The rachis is $1-2 \mathrm{~mm}$ wide. The lamina of the attachment area of the pinnae is expanded (10 $\mathrm{mm}$ wide). Linear pinnules appear on the pinna rachis about 30-40 mm from the base; basal pinnules are short (20 mm long) and increase apically in size (up to $65 \mathrm{~mm}$ ), while the width stays constant $(2 \mathrm{~mm})$. Pinnules are attached perpendicularly and with the entire width to the pinnae rachis; apical pinnules are inserted with an acute angle. Distance between basal pinnules is about $2 \mathrm{~mm}$ (rarely up to $4 \mathrm{~mm}$ ), this distance decreases towards the apex, and pinnules may overlap almost over their entire length. The margin of the pinnules is entire, apex subacute. The lamina on both sides of the midrib is divided into almost square bulging units (about $0.7 \times 1 \mathrm{~mm}$ ) by secondary veins arising almost perpendicularly from the midrib (Fig. 4g). These veins branch on the bulging units nearly parallel to the midrib and subsequently 2-3 times diagonally across the units. Sori are attached on the fertile fronds within the units, in few remains of sporangia are preserved $(0.3 \times 0.5 \mathrm{~mm}$, Fig. $5 \mathrm{~b})$.

Remarks. The Hungarian specimens are preserved mostly as small fragments, with the exception of one almost complete frond base, but the distinctive gross morphology (i.e. venation pattern) permits an attribution to $P$. angustiloba. Characteristic for this species is the presence of "rectangular units". They are slightly convex on sterile fronds and distinctively convex on fertile fronds, indicating that the structure is independent from the presence of sori (Harris 1931). Schenk (1867, pl. 18, fig. 10) showed a similar venation pattern with only one bifurcation at half lamina and a second vein arising from the base and extending up to the attachment of the sori at the middle part of the lamina.

In the past, sterile fragments were often attributed to the genus Andriana Braun 1840 (A. baruthina Braun 1840, A. norimbergica Gothan 1914), whereas fertile specimens were assigned to G. angustiloba Presl in Sterneberg 1838. Krasser (1922), for example, mentioned A. baruthina, from the Mecsek Mts. but without description or illustration. Gothan (1914) distinguished the three fossil taxa mentioned before and excluded an affinity with the genus Laccopteris (junior synonym of Phlebopteris). Harris (1931) considered $G$. angustiloba and $A$. baruthina conspecific and moved them to Laccopteris (younger synonym of Phlebopteris). We agree with Harris and consider all three species conspecific and belonging to the genus Phlebopteris

Each sorus of $P$. angustiloba consists of eight sporangia (Lundblad 1950). The in situ spores are generally trilete, sub-triangular (30-55 $\mu \mathrm{m}$ in diameter) with a distinct opening, interradial thickenings and a smooth exine (e.g., Schenk 1867; Harris 1931; Reymanówna 1963; Van Konijnenburgvan Cittert 1993). The same spore type, belonging to the dispersed genus Deltoidosporites Danzè-Corsin and Lavein 1963, was described by Schenk (1867) for A. baruthina. Unfortunately, our material is to highly coalified for any sporangia details, but Götz et al. (2011) mentioned Deltoidospora for the Upper Triassic to Lower Jurassic sediments of Hungary.

Material. BP 89.96.1, 89.123.1, 89.192.1-193.1, 89.336.1, 89.339.1-440.1, 89.455.1, 89.482.1, 89.484.1-485.1, 89.488.1, 94.181.1, 94.454.1, 94.474.1-476.1, 94.482.1483.1, 94.485.1, 94.509.1, 94.549.1, 94.601.1, 94.603.1, $94.642 .1,94.653 .1-655.1,94.681 .1,94.685 .1,94.725 .1-$ 726.1, 94.728.1, 94.791.1-793.1, 94.931.1, 96.121.1, 96.185.1, 98.791.1, 98.975.1, 2002.38.1 (42 specimens)

Phlebopteris kirchneri Barbacka and Kustatscher sp. nov. Figures 5c-g, 6a-g

Synonyms.

1961 Phlebopteris muensteri (Schenk) Hirmer et Hörhammer-Nagy: p. 618, pls. 8, 10.

1961 Phlebopteris aff. polypodioides Brongniart-Nagy: p. 619, pl. 7, fig. 1.

? 1997 Phlebopteris sp. Kostina and Doludenko; p. 187, figs. $7 \mathrm{~b}, 8 \mathrm{k}$.

Etymology. In honor of Martin Kirchner who studied extensively the Rhaetian to Early Jurassic flora of Bayreuth (Germany). 

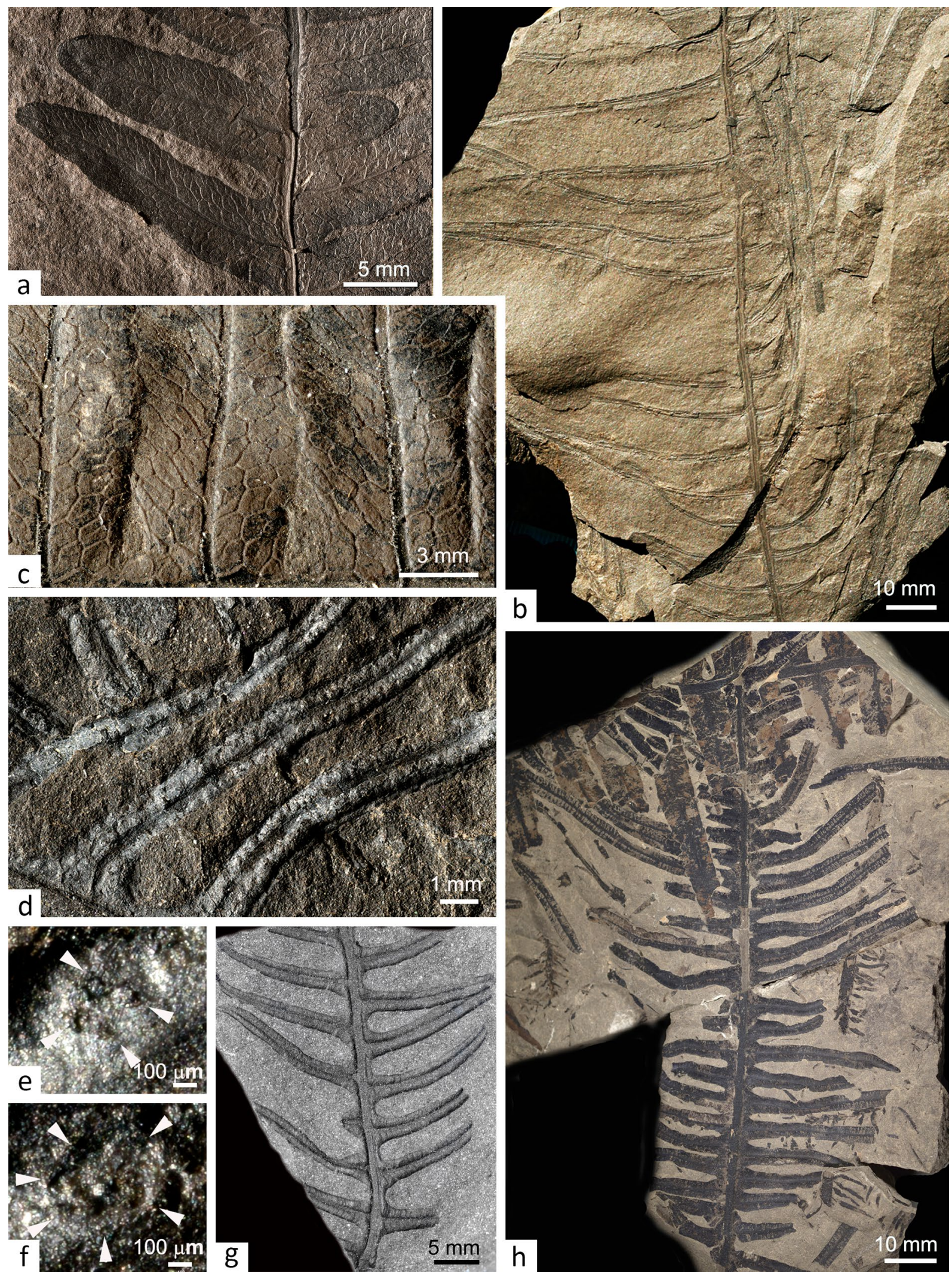
४Fig. 6 Ferns of the Early Jurassic of Hungary. a Detail of sterile pinnules with clear venation pattern of Phlebopteris kirchneri Barbacka and Kustatscher sp. nov. (photo MS); b fertile pinna fragment of Phlebopteris kirchneri Barbacka and Kustatscher sp. nov., paratype, No. 2004.69.1. c Detail of sterile pinnules with clear venation pattern of Phlebopteris kirchneri Barbacka and Kustatscher sp. nov., details of venation, No. 94.291.1. (photo MS); d detail of fertile pinnules with imprints of the sori of Phlebopteris kirchneri Barbacka and Kustatscher sp. nov., No. 2003.461.1. (photo MS); e, f details of Fig. 5d showng impressions of sporangia. (photo MS); $\mathbf{g}$ fertile pinna fragment of Phlebopteris kirchneri Barbacka and Kustatscher sp. nov., No. 94.522. (photo MS); h sterile pinna fragment of Matonia braunii (Goeppert) Harris 1980, No. 89.339.1. (photo MS)

Holotype. No 96.266.1. Hungarian Museum of Natural History, Fig. 5d, hic designatus.

Paratype. No 2004.69.1. Hungarian Museum of Natural History, Fig. 6b, hic designatus.

Type locality. Pécsbánya (near Pécs), Mecsek Mountains, Southern Hungary.

Locality and stratigraphic horizon. Pécsbánya (near Pécs), Mecsek Mountains, Southern Hungary, Mecsek Coal Formation, Hettangian, Early Jurassic.

Repository. Botanical Department of the Hungarian Natural History Museum, Budapest

Diagnosis. Fronds palmate, large. Pinnae pinnate, free from the base, fertile fronds differ from sterile ones. Sterile pinnules linear, long, margins entire or slightly waved, apex subacute. Pinnule bases as wide as the pinnule or slightly extended, touching, crowded, but not overlapping. Midrib conspicuous, secondary veins forming ovoid, rhomboid, or hexagonal meshes of almost equal size, running in two or three rows along the pinnule. Sterile and fertile pinnules mixed on the same pinnae, or on separate pinnae or separate fronds. Fertile pinnules narrow linear, widely spaced, or bases extended, in touch, apex subacute. Midrib distinct, secondary veins delicate. Round sori detached, densely inserted in single rows on both sides of the midrib, 5-6 sporangia each sorus.

Description. The fronds are palmate with more or less regular pinnae bases. The petiole is up to $7 \mathrm{~mm}$ wide and branches into 4-5 separate pinnae. Sterile and fertile pinnules are distributed mostly on distinct pinnae and fronds, but mixed pinnae and fronds have been observed as well Fig. 5e, f). Occasionally, pinnules are basally sterile with a fertile apex (Fig. 5c). Sterile and fertile pinnules differ in shape and dimension. Pinnules are linear with an obtuse apex and a slightly extended (sometimes touching), rarely constricted base. Margins are almost parallel, entire or slightly undulated. The midrib is distinct, secondary veins form a net of oval-rhomboid-hexagonal meshes of equal size, running in 2-3 rows along the midrib (Figs. 5g, 6c). Sterile pinnules are lanceolate (Fig. 5d). Basal pinnules are small (from $3 \times 10 \mathrm{~mm}$ ), but increase in dimension towards the middle part of pinna. They reach up to $85 \mathrm{~mm}$ in length and up to $5 \mathrm{~mm}$ in width. The distance between neighbouring pinnules is $1-3 \mathrm{~mm}$. Fertile pinnules are narrower ( $2 \mathrm{~mm}$, max $4 \mathrm{~mm}$ ) and up to $90 \mathrm{~mm}$ long, the basal ones are $\sim 15 \mathrm{~mm}$ long (Fig. 6b). They are widely spaced, with a distance of $3-18 \mathrm{~mm}$. The midrib is distinct, but secondary veins are rarely visible. They form two rows of net meshes, where the second row may be incomplete with open meshes near the margin. Sori are always detached, only slight imprints are visible on the lower surface of the pinnules. They are round, about $1 \mathrm{~mm}$ in diameter with five to six (?) sporangia each (Fig. 6e, f). In situ spores are unknown.

Comparisons. Phlebopteris kirchneri Barbacka and Kustatscher sp. nov. differ from all other taxa because of its very regular venation pattern, consisting of the oval-to hexagonal meshes formed by secondary veins; shape, size and arrangement of the meshes are very constant in the specimens. In other species secondary veins near the midrib form relatively large, more or less prominent primary arches from which veins run towards the pinnule margin and anastomize, developing irregularly elongated meshes similar to Phlebopteris polypodioides Brongniart 1828, P. woodwardii Leckenby 1864 or P. affinis (Schenk) Seward 1900. Veins do not form meshes but are pinnate with a variable number of forking of the secondary veins in $P$. dunkeri Schenk 1871, P. angustiloba, P. braunii Göppert 1841 or P. muensteri (Schenk) Hirmer and Hörhammer 1936. Additionally, distinctive features are the distance between pinnules and the much narrower shape in fertile fronds. Fertile pinnules show a high variability in dimension and shape; this becomes visible because of the large number of studied sampled P. kirchneri Barbacka and Kustatscher sp. nov. resembles P. tracyi Ash 1991 from the Jurassic of Oregon and Idaho in general pinnule morphology and the reticulate pattern of the secondary veins at the pinnule margin. The basal (near the midrib) net venation is, however, more distinct and more regular in the new species. Phlebopteris otongensis Weber 2008 from the Jurassic of Mexico, has smaller linear to triangular pinnules $(5.5 \times 1.5 \mathrm{~mm})$ and the crowded, sometimes anastomosing veins. In P. muensteri from the Early Jurassic of Europe and Asia the pinnules are larger (at least $60 \times 4-5 \mathrm{~mm}$ ), have a thick midrib and simple to twice forked lateral veins with a higher vein concentration (30-40 per $\mathrm{cm}$ ). The pinnules are also bigger (80-150×10-14 mm) in P. formosa (Givulescu and Popa) Schweitzer et al. 2009 from the Early Jurassic of Romania. The lateral veins arise at $2-3 \mathrm{~mm}$ interval in the latter species, and bifurcate often giving origin to an almost 

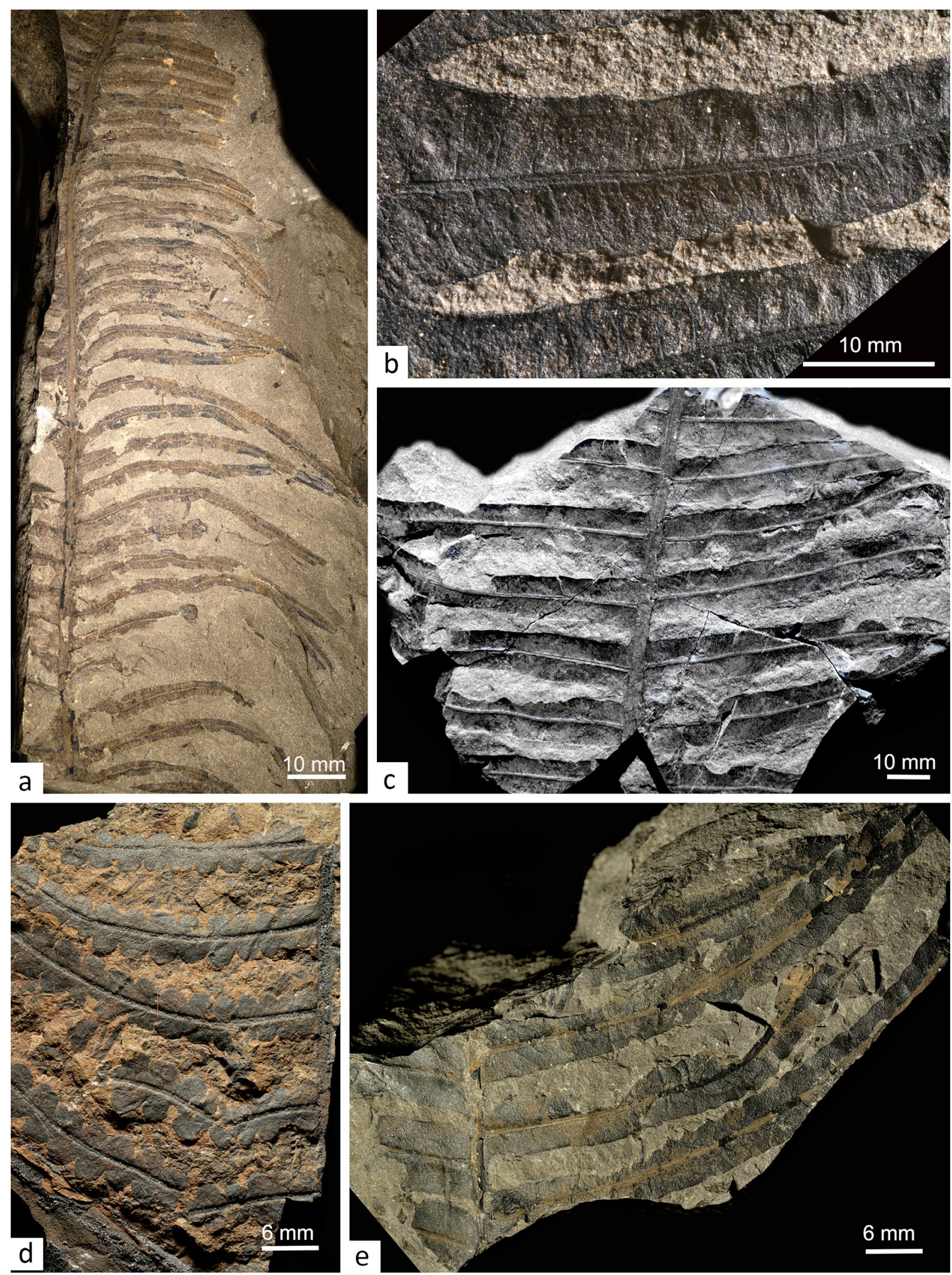
४Fig. 7 Ferns of the Early Jurassic of Hungary. a Fertile pinna fragment of Matonia braunii (Goeppert) Harris 1980, No. 89.336.1. (photo MS); b Sterile pinnules with venation pattern of Matonia braunii (Goeppert) Harris 1980, No. 89.339.1. (photo MS); c Sterile pinna fragment with entire margins of Thaumatopteris brauniana Popp 1863, No. 94.543.1; d Sterile pinna fragment with deeply insised margins of Thaumatopteris brauniana Popp 1863, No. 94.486.1. (photo MS); e Sterile pinna fragment with partly entire and partly incised margins of Thaumatopteris brauniana Popp 1863, No. 94.602.1. (photo MS)

fasciculate structure. Venations similar to those described here may also occur in P. woodwardii Leckenby 1864; however, the lamina of the latter species is very thick and generally preserved as fusain.

Remarks. This species is the most abundant among the ferns from Mecsek Mountains. The sterile and fertile frond fragments evidence a high variability in size and distance between single pinnules, especially in fertile ones. Venation pattern and frond shape, on the other hand, are consistent within the group. The specimens from the Mecsek Mts. described by Nagy (1961) as P. muensteri and P. aff. polypodioides, correspond to the sterile and fertile pinnae of P. kirchneri Barbacka and Kustatscher sp. nov., respectively; P. muensteri and P. polypodioides are not represented in this locality. P. kirchneri Barbacka and Kustatscher sp. nov. resembles also two specimens figured by Kostina and Doludenko (1997) from the Middle Jurassic of Siberia that show the same coarse reticulum as our specimens and could belong to the same species.

Material. BP 89.29.1, 89.300.1-302.1, 89.306.1-308.1, 89.335.1, 89.343.1, 89.345.1, 89.447.1, 89.465.1, 89.476.1, 89.478.1, 89.486.1, 89.489.1, 89.493.1, 89.495.2, 94.135.1, 94.248.1, 94.256.1, 94.291.1, 89.303.1, 94.312.1-313.1, 94.321.1, 94.333.1, 94.391.1-392.1, 94.472.1, 94.507.1, 94.522.1, 94.544.1, 94.566.1, 94.593.1, 94.658.1, 94.662.1, 94.729.1, 94.736.1, 94.784.1, 94.859.1, 94.862.1-863.1R, 94.996.1-998.1, 94.1000.1, 96.12.1-13.1, 96.134.1135.1, 96.217.1, 96.230.1-232.1, 96.237.1-249.1, 96.256.1, 96.262.1-263.1, 96.266.1, 96.384.1, 96.387.1, 96.391.1, 98.53.1, 98.98.1, 98.178.1, 98.249.1, 98.341.1, 98.423.1, 98.584.1-595.1, 98.597.1, 98.713.1-714.1, 98.750.1, 98.778.1-792.1, 98.927.1, 98.1075.1, 98.1102.1, 2000.1282.1, 2000.1285.2, 2000.1287.1, 2001.625.1, 2001.979.1, 2002.4.1-15.1, 2002.17.1, 2002.19.1, 2002.25.1, 2003.190.1, 2003.446.1-457.1, 2003.461.1, 2003.471.1-473.1, 2004.61.1-78.1, 2004.1016.1, 2004.1090.1, 2004.1104.1-1111.1, 2004.1113.1, 2004.1184.1-1185.1, 2004.1199.1, 2005.639.1, 2005.642.1-643.1, 2005.885.1, 2005.890.1, 2005.949.1, $2005.959 .1,2006.680 .1,2006.682 .1,2006.684 .1-$ 2006.689.1, 2007.142.1, 2007.144.1-145.1, 2007.147.1,
2007.149.1-152.1, 2007.154.1, 2007.156.1, 2007.159.1, 2007.170.1-174.1, 2007.199.1, 2007.816.1, 2007.820.1, 2007.871.1, 2007.908.1. (172 specimens).

Genus Matonia R. Brown in Wallich 1830

Matonia braunii (Goeppert) Harris 1980

Figures $6 \mathrm{~h}, 7 \mathrm{a}, \mathrm{b}$

Selected synonyms.

1980 Matonia braunii (Goeppert)—Harris: p. 296-300, text figs. 1-20.

1997 Matonia braunii (Goeppert) Harris_Popa: fig. 19.

1999 Matonia braunii (Goeppert) Harris-Van Konijnenburg-van Cittert and Morgans: p. 47, pl. 2, fig. 4, text fig. 21C.

2016 Matonia braunii (Goeppert) Harris—Barbacka et al.; p. 860 , figs. $2-5$.

Description. The frond is palmately compound with pinnate pinnae. The fertile and sterile frond fragments were not found in anatomical connection, but share the same gross morphology. Both sterile and fertile pinnules are oppositely to suboppositely insert on the rachis. The lamina of neighbouring pinnules joins at the base, forming an about $1 \mathrm{~mm}$ wide, $\mathrm{U}$-shaped web along the rachis. The biggest sterile pinnule fragment is $57 \mathrm{~mm}$ long (with an estimated length of $70 \mathrm{~mm}$ ), the longest fertile pinnule is more than $80 \mathrm{~mm}$ (incomplete). The width of both pinnule types is similar $(3 \mathrm{~mm})$ and both narrow before the subacute apex. The distinct midrib runs up to the apex. Secondary veins are delicate, arise nearly perpendicularly to the midrib and fork once, usually close to the margin (Fig. 7b). They form rectangular, slightly bulging units clearer visible in the fertile pinnules. Sori are poorly and only sporadically preserved, with up to six sporangia. Fragments of annuli are present, but badly preserved; indusia are not observed.

Remarks. The fern remains show clear similarities with $P$. braunii Göppert 1841 including the pinnae size, pinnule shape and arrangement, venation pattern and sori. Harris (1980) considered the sterile fronds $P$. braunii and the fertile fronds P. muensterii Schenk 1867 as belonging to the same natural species and attributed them to the genus Matonia due to the presence of indusia characteristical for this genus. He considered specimens without indusia as having lost them, similar to extant Matoniaceae in which indusia detach very easily. This was confirmed by the discovery of $M$. braunii fronds with indusia in Lower Jurassic sediments of Poland (Barbacka et al. 2016). Although venation was poorly preserved in the Polish specimens, its pattern and 


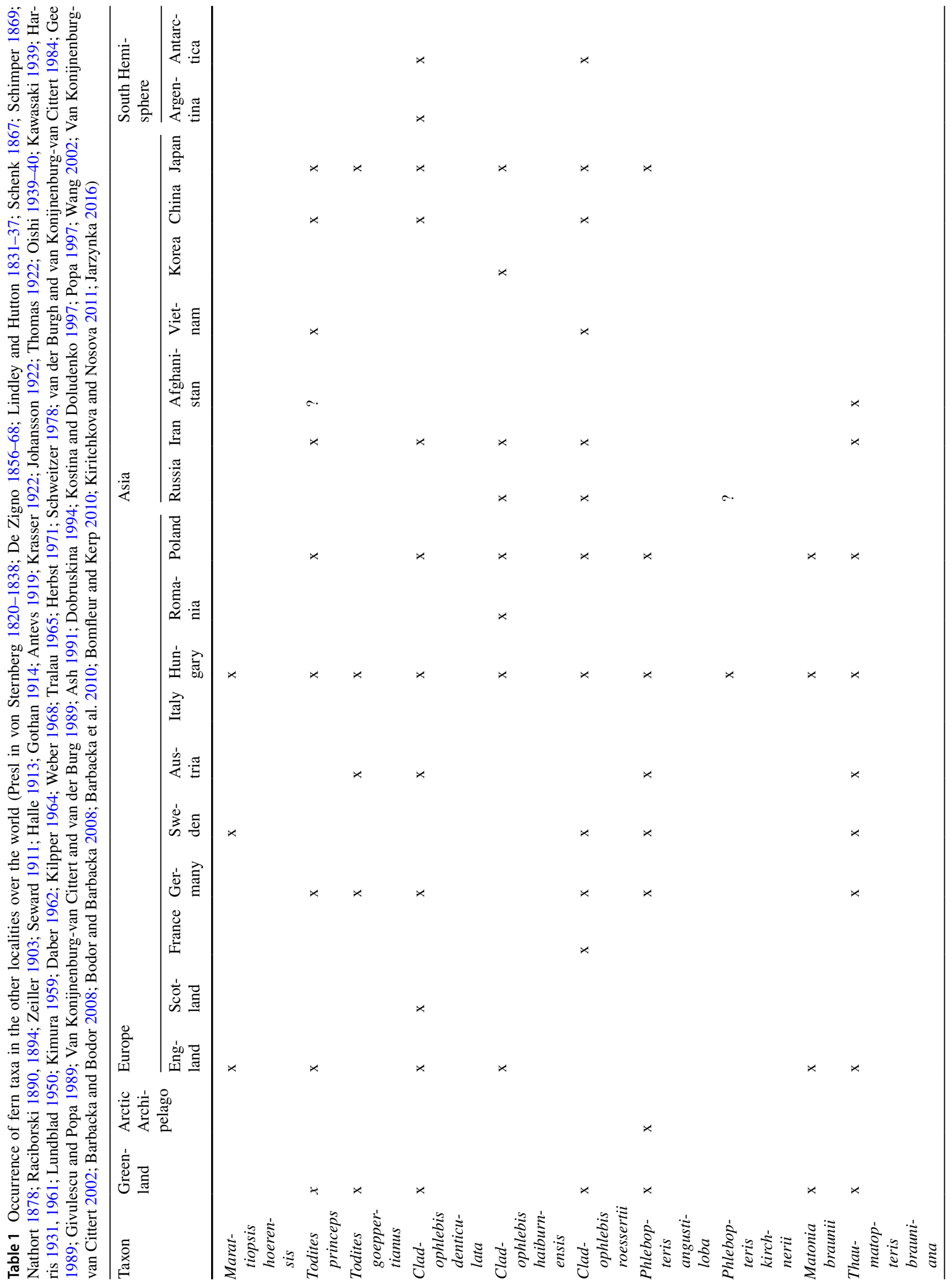




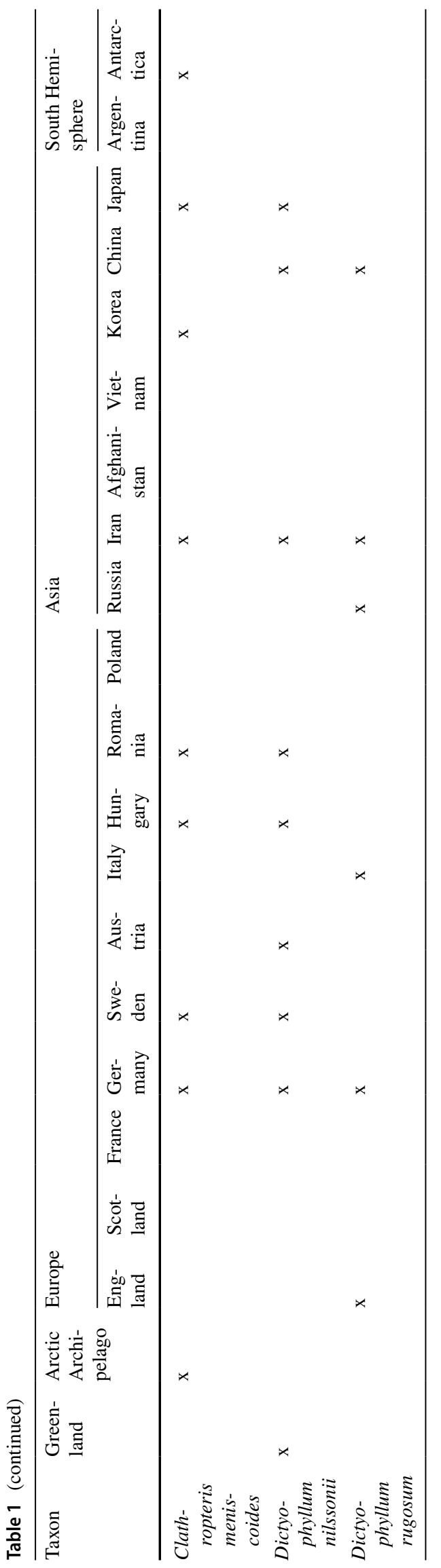

other morphological features correspond with our remains from Hungary even if in our case indusia were not found. This species is well known from the Jurassic of Greenland and Europe (Table 1).

Material. BP 89.123.1, 89.336.1, 89.339.1, 89.488.1, 89.488.1R, 94.601.1, 94.603.1, 94.642.1, 94.791.1, 94.931.1 (10 specimens)

Family Dipteridaceae Seward and Dale 1901

Genus Thaumatopteris Göppert 1841

Thaumatopteris brauniana Popp 1863

Figures 7c-e, 8a

Selected synonyms (for more details see Schenk 1867; Harris 1931, Schweitzer 1978).

1863 Thaumatopteris brauniana-Popp: p. 409.

1867 Thaumatopteris brauniana Popp-Schenk: p. 73-75, pl. 18, figs. 1-3, pl. 19, fig. 1 .

1878 Thaumatopteris schenkii-Nathorst: p. 46, pl. 2, fig. 1 .

1914 Thaumatopteris schenkii Nathorst-Gothan: p. 1045, pl. 19, figs. 3, 3a.

1922 Thaumatopteris brauniana Popp emend. NathorstKrasser: p. 351.

1922 Thaumatopteris schenkii Nathorst-Krasser: p. 353.

1931 Thaumatopteris schenkii Nathorst-Harris: p. 93-94, pl. 17 , figs. 6-8, pl. 18, figs. 1-2, text-fig. 35 .

1931 Thaumatopteris brauniana Popp-Harris: p. 94-96, pl. 17, figs. 5, pl. 18, figs. 4, 6-11, 13, text-fig. 36.

1950 Thaumatopteris brauniana Popp_Lundblad: p. 27, pl. 4, figs. 1-2.

1950 Thaumatopteris schenkii Nathorst_Lundblad: p. 28, pl. 3, figs. 10-11, pl. 4, fig. 1.

1961 Thaumatopteris schenki Nathorst-Nagy: p. 622, pl. 11, fig. 2.

1978 Thaumatopteris brauniana Popp-Schweitzer: p. 36, pl. 4, figs. 5-9, pl. 5, figs. 1-7, pl. 6, figs. 1-3; textfigs. 20, 23, 24, 26-28, 30-31.

1997 Thaumatopteris sp.-Popa: figs. 8-11.

2003 Thaumatopetris brauniana (Popp) SchweitzerPopa et al.: p. 362-364, pl. 1, figs. 1-5,

Description. Fronds are palmate, with fertile and sterile fronds similar in morphology. From each basal branch a maximum of seven pinnae arise. Pinnae are linear to lanceolate; the fragments reach a maximal length of $250 \mathrm{~mm}$, but the shape permits a much higher estimation for the total length. The longest pinnules are in the middle part of the pinna, with decreasing length towards base and apex. The 

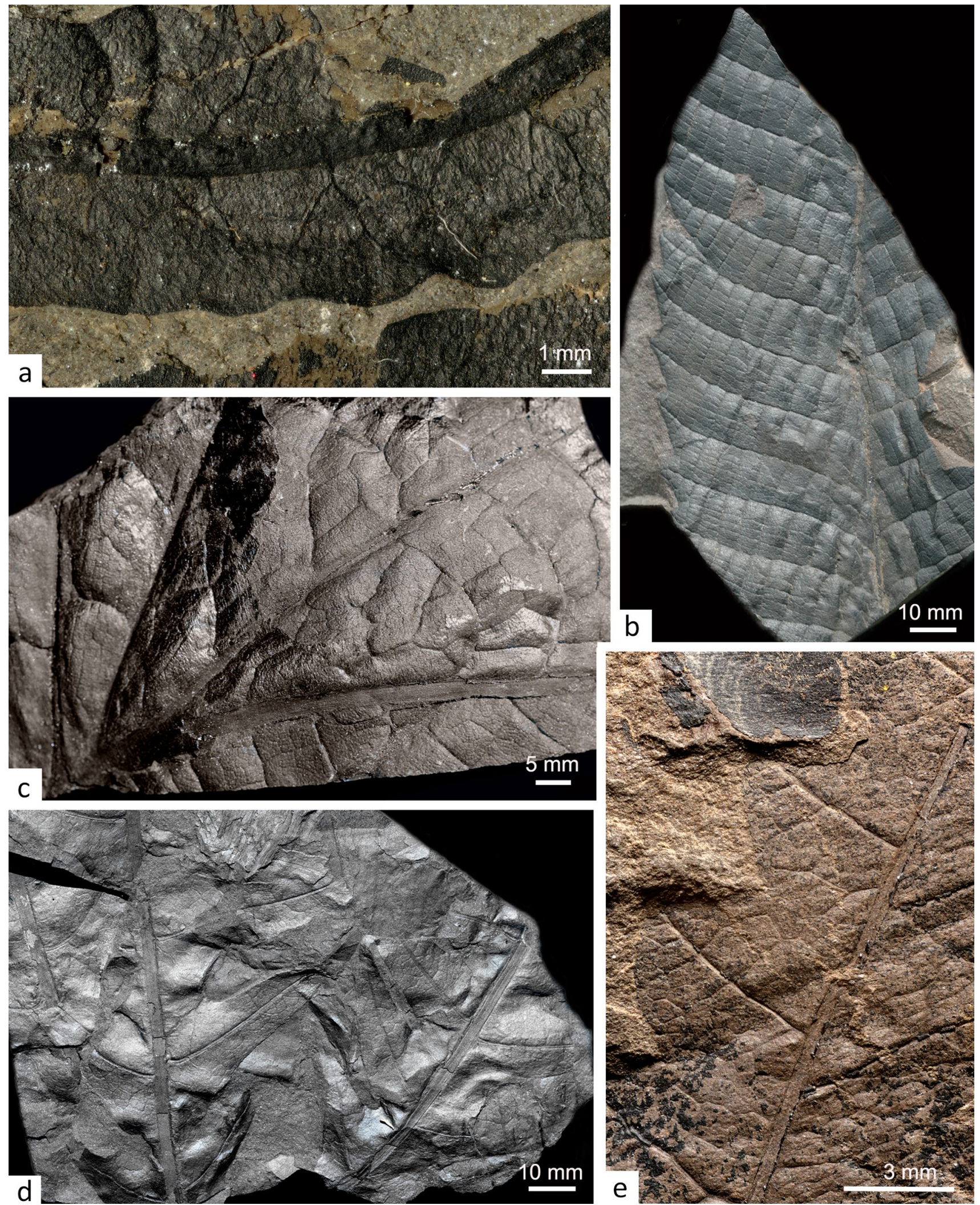

Fig. 8 Ferns of the Early Jurassic of Hungary. a Thaumatopteris brauniana Popp 1863, sterile pinnules with venation pattern, details from Fig. 7f. (photo MS). b Pinna fragment of Clathropteris meniscoides Brongniart 1835-36, No. 98.342.1. c Base of frond of Clath- ropteris meniscoides Brongniart 1835-36, No. 89.315.1. d Frond fragment of Dictyophyllum nilssonii (Brongniart) Goeppert 1846, No. 96.78.1. e Frond fragment of Dictyophyllum nilssonii (Brongniart) Goeppert 1846, No. 96.221.1 (photo MS) 
rachis is $1.5-4 \mathrm{~mm}$ wide and slightly striated. Pinnules arise perpendicularly from the rachis, with a usual distance between adjacent pinnules of $3 \mathrm{~mm}$ (max. $10 \mathrm{~mm}$ ). Pinnule bases range from slightly constricted to slightly extended. Pinnules are elongate with a subacute apex, up to $10 \mathrm{~mm}$ long and $10 \mathrm{~mm}$ wide at the pinna base, increasing to more than $130 \mathrm{~mm}$ (incomplete) in length, and up to $13 \mathrm{~mm}$ in width in the middle. The pinnule margin is often entire (Fig. 7c), though it may be waved to deeply incised (reaching the midrib, Fig. 7d). The ratio of fragments with entire margis to those with incised margins is 5:1. Frequently, the margin is entire in the basal portion and becomes waved or incised towards the apex (Fig. 7e). The midrib is distinct, secondary veins divide once near the midrib and form a net of delicate veins with nearly hexagonal meshes (the smallest meshes are $0.3 \mathrm{~mm}$ wide, Fig. 8a). Sori are globose with a diameter of $0.8-1 \mathrm{~mm}$, but fertile specimens are poorly preserved.

Remarks. The Hungarian frond fragments show a high variability in size and margin of the pinnules. Forms with different margins were originally distinct in separate fossil species, e.g., Thaumatopteris schenki Nathorst 1878 with incised margins, T. brauniana Popp 1863 with entire margins, T. variabilis Stanislawski 1976 with partly entire and partly incised pinnules and T. bipinnata Kilpper 1964 with deeply incised margins giving almost the idea of a bipinnate structure. Schweitzer (1978) interpretted the different pinnule forms as a result of natural leaf variability and included the above mentioned species in T. brauniana according to its nomenclatural priority. Moreover, Schweitzer et al. (2009) suggested that there was no fundamental difference in leaf morphology between Thaumatopteris and Dictyophyllum. Harris (1931) and Schweitzer et al. (2009) proposed to distinguish between the two genera based on the sori position, dimension and number of sporangia, and in case those are missing, to treat the specimens as Dictyophyllum. Since the type species of Thaumatopteris, T. muensteri Göppert, 1841 has been moved by Nathorst (1875) to Dictyophyllum, the genus Thaumatopteris is now without type species. The currently best defined fossil taxon of Thaumatopteris is $T$. brauniana (Schweitzer et al. 2009) but the genus will need to be conserved (pers. Comm. van Konijenenburg-van Cittert 2018). Krasser (1922) and Nagy (1961) mentioned $T$. schenki and T. brauniana from the Mecsek Mts, but we follow Schweitzer (1978) using the name T. brauniana.

Material. BP 89.332.1, 89.338.1, 89.343.1R, 89.347.1, 89.458.1, 89.466.1-467.1, 89.469.1-471.1, 89.473.1, 89.483.1, 89.488.1, 89.494.1, 94.175.1, 94.231.1, 94.441.1, 94.448.1-449.1, 94.467.1, 94.486.1- 489.1, 94.498.1, 94.508.1, 94.531.1, 94.543.1, 94.545.1-547.1, 94.554.1, 94.593.1, 94.601.1-602.1, 94.605.1-607.1, 94.652.1,
94.690.1, 94.695.1, 94.725.1, 94.730.1, 94.767.1, 94.794.1795.1, 94.822.1, 94.825.1-826.1, 94.828.1, 94.830.1-831.1, 94.860.1-863.1, 96.129.1-131.1, 96.136.1, 96.146.1, 96.175.1, 96.223.1, 96.383.1-384.1, 96.403.1, 98.582.1, 2004.73.2, 2004.1113.1 (53 specimens)

\section{Genus Clathropteris Brongniart 1828}

\section{Clathropteris meniscoides Brongniart 1835-36}

Figure 8b, c

Selected synonyms (for more details see Schenk 1867; Johansson 1922; Harris 1931).

1825 Filicites meniscoides-Brongniart: p. 200, pls. 11-12.

1828 Clathropteris meniscoides-Brongniart: p. 62, 194.

1841 Clathropteris platyphylla-Göppert: pl. 18, 19, figs. 1-3.

1867 Clathropteris platyphylla Brongniart-Schenk: p. 81-86, pl. 16, figs. 2-9, pl. 27.

1914 Clathropteris platyphylla Göppert-Gothan: p. 107.

1922 Clathropteris meniscoides Brongniart—Johansson: p. 10, pl. 4, fig. 13, pl. 5, figs. 53-56.

1931 Clathropteris meniscoides Brongniart-Harris: p. 88-93, pl. 15, figs. 1, 9, pl. 16, figs. 9-10, pl. 13, figs. 3, 5, 12, text-figs. 32-34.

1939-40 Clathropteris meniscoides Brongniart-Oishi: p. 214-16, pl. 3, figs. 1, 1a.

1989 Clathropteris meniscoides BrongniartGivulescu: p. 19.

2002 Clathropteris meniscoides Brongniart-Van Konijnenburg-van Cittert: p. 120.

Description. The frond is large, palmate with long pinnae. The only petiole preserved is $16 \mathrm{~mm}$ wide and divides apically into two short branches from which originate at least four pinnae. The lamina of all pinnae is fused at their base over a distance of several centimetres giving origin to a solid fan-shaped basis. The largest preserved base fragment is $25 \mathrm{~cm}$ long with four pinna bases fused over a distance of more than $20 \mathrm{~cm}$. The pinnae are elongated truncate, sometimes linear with an enlarged base and a subacute apex. The pinna width varies depending on the size of the frond and its position on the frond. The narrowest pinna fragment is $20 \mathrm{~mm}$ wide (apical?), the broadest (middle part?) $90 \mathrm{~mm}$. Margins are waved to serrate, teeth vary in size within one pinna, up to a maximum of $5 \mathrm{~mm}$. Midrib is marked, 1-4 mm wide, and extending up to the apex. Secondary veins form distinct polygones, each divided by meshes of fine tertiary veins. The meshes of the secondary veins are 
irregular in shape and size at the base of the lamina, but rectangular, from $5 \times 2 \mathrm{~mm}$ to $14 \times 6 \mathrm{~mm}$, in the pinna. No fertile fronds were observed, despite the large number of specimens.

Remarks. According to several authors (e.g., Harris 1931; Johansson 1922) C. meniscoides and C. platyphylla Göppert 1841 are conspecific with $C$. meniscoides having priority. C. lunzenzis Stur 1881 differs from C. meniscoides in its larger marginal teeth (Harris 1931). The specimens from the Mecsek Mts. show a high variability in gross-morphology and pinnae shape and venation but fall within the species variability of C. meniscoides. Krasser (1922), Nagy (1961) and Van Konijnenburg-van Cittert (2002) considered it a common fern in the Jurassic flora of Hungary.

Material. BP 60.158.1, 89.41.1-45.1, 89.47.1-64.1, 89.66.1, 89.69.1, 89.76.1-77.1, 89.79.1-81.1, 89.84.1, 89.87.1, 89.90.1-91.1, 89.94.1, 89.98.1, 89.101.1, 89.112.1, 89.114.1-116.1, 89.118.1, 89.120.1-122.1, 89.124.1, 89.126.1, 89.134.1, 89.137.1, 89.141.1-144.1, 89.171.1, 89.314.1-316.1, 89.324.1, 89.326.1, 89.333.1, 89.340.1, 89.342.1, 94.76.1, 94.267.1, 94.332.1, 94.337.1, 94.472.1473.1, 94.508.1, 94.561.1-573.1, 94.577.1-591.1, 94.729.1730.1, 94.733.1, 94.736.1, 94.740.1, 96.137.1, 96.451.1, 98.270.1, 98.709.1-98.715.1, 2001.967.1, 2004.1112.1, 2005.648.1, 2005.900.1, 2005.941.1, 2007.138.1, 2007.145.1, 2007.147.1-150.1, 2007.157.1-159.1, 2007.176.1-184.1, 2007.896.1, 2007.954.1, 2009.467.1 (147 specimens)

Genus Dictyophyllum Lindley and Hutton 1834

\section{Dictyophyllum nilssonii (Brongniart) Goeppert 1846 Figure 8d, e}

Selected synonyms (for more details see Harris 1931).

1836 Phlebopteris nilssoni-Brongniart: p. 376, pl. 132, fig. 2.

1846 Dictyophyllum nilssoni Brongniart-Goeppert: p. 119.

1922 Dictyophyllum nilssonii (Brongniart) Goeppert-Krasser: p. 350.

1831 Dictyophyllum nilssonii (Brongniart)—Goeppert: p. $81-85$, pl. 14 , fig. 4 , pl. 15 , figs. 3 , $5,6,8$, pl. 16 , figs. $1-5,7,8$, pl. 17 , fig. 9 , text-figs. 29-30.

1939-40 Dictyophyllum nilssonii (Brongniart) GoeppertOishi: p. 218-9.

1962 Dictyophyllum nilssonii (Brongniart) GoeppertDaber: p. 131-132, pl. 4, fig. 7.
1968

Dictyophyllum nilsonii (Brongniart) GoeppertWeber: p. 49-50, pl. 8, figs. 67-72.

1997

2002

Dictyophyllum nilssonii (Brongniart) GoeppertPopa: figs. 1-4.

Dictyophyllum nilssonii (Brongniart) GoeppertWang: p. 130, 133.

Description. The species is represented in the flora only by sterile frond fragments. The fronds are palmate with up to 12 pinnae arising from a $10-20 \mathrm{~mm}$ wide petiole. Pinnae are lanceolate, $20-45 \mathrm{~mm}$ wide with a midrib of $1-4 \mathrm{~mm}$ width. The pinna margin is lobed with more or less deep incisions. Basally, below the first lobes, and near the apex the lamina is entire, $20-30 \mathrm{~mm}$ wide with slightly waved margins. Lobes start 30-40 $\mathrm{mm}$ from the base of the pinnae. They have a wide base, but radically narrow towards the apex which is usually obtuse. Lobes along the pinnae vary in form and size, from narrow $(30 \times 5-6 \mathrm{~mm})$ to wide $(50 \times 13-25 \mathrm{~mm})$ and are acroscopically enlarged. The margins of lobes are entire to slightly waving. The main vein of the lobes arises from the midrib and runs up to the tip of the lobes. Secondary veins form rounded, polygonal to irregular meshes.

Remarks. The flora of Hungary yielded so far only sterile frond fragments. Harris (1931) described different pinnae of $D$. nilssonii with transitional forms from Greenland, that convinced him to consider some earlier species, such as D. spectabilis Nathorst 1906, D. nilssonii var. hoerense Nathorst 1906, Dictyophyllum acutilobum (Braun) Schenk 1867 p.p. and D. obtusilobum Schenk 1867 p.p., as synonyms of $D$. nilssonii. The main criteria to distinguish the species, according to Harris (1931), are frond size, pinnae morphology (length and lobation) and features of sporangia. Sterile and fertile fronds have a similar morphology, although large fronds are more often fertile. Sporangia are scattered and do not form sori; they are attached above small veins in the meshes (Harris 1931). Harris (1931) used the terms "pinnules" for lobes and "rachis" for the midrib of the pinna. Since the lobes in fact do not correspond to separated pinnules, we prefer to use lobes as proposed by Seward (1911).

Dictyophyllum nilssonii differs from all other species because of its robust fronds, generally wide and short lobes and sporangia size. However, marginal lobes in the pinnae may be confusing, since very long lobes may have lobed margins (e.g., Dictyophyllum rugosum or large forms of $D$. nilssonii; Harris 1931), resembling Thaumatopteris braunii. In the Mecsek Mts. D. nilssonii is common and its frond show a high variability in size and shape of the lobes.

Material. BP 89.10.1, 89.12.1, 89.28.1, 89.67.1, 89.70.1, 89.89.1, 89.440.1, 89.455.1-456.1, 89.459.1-461.1, 


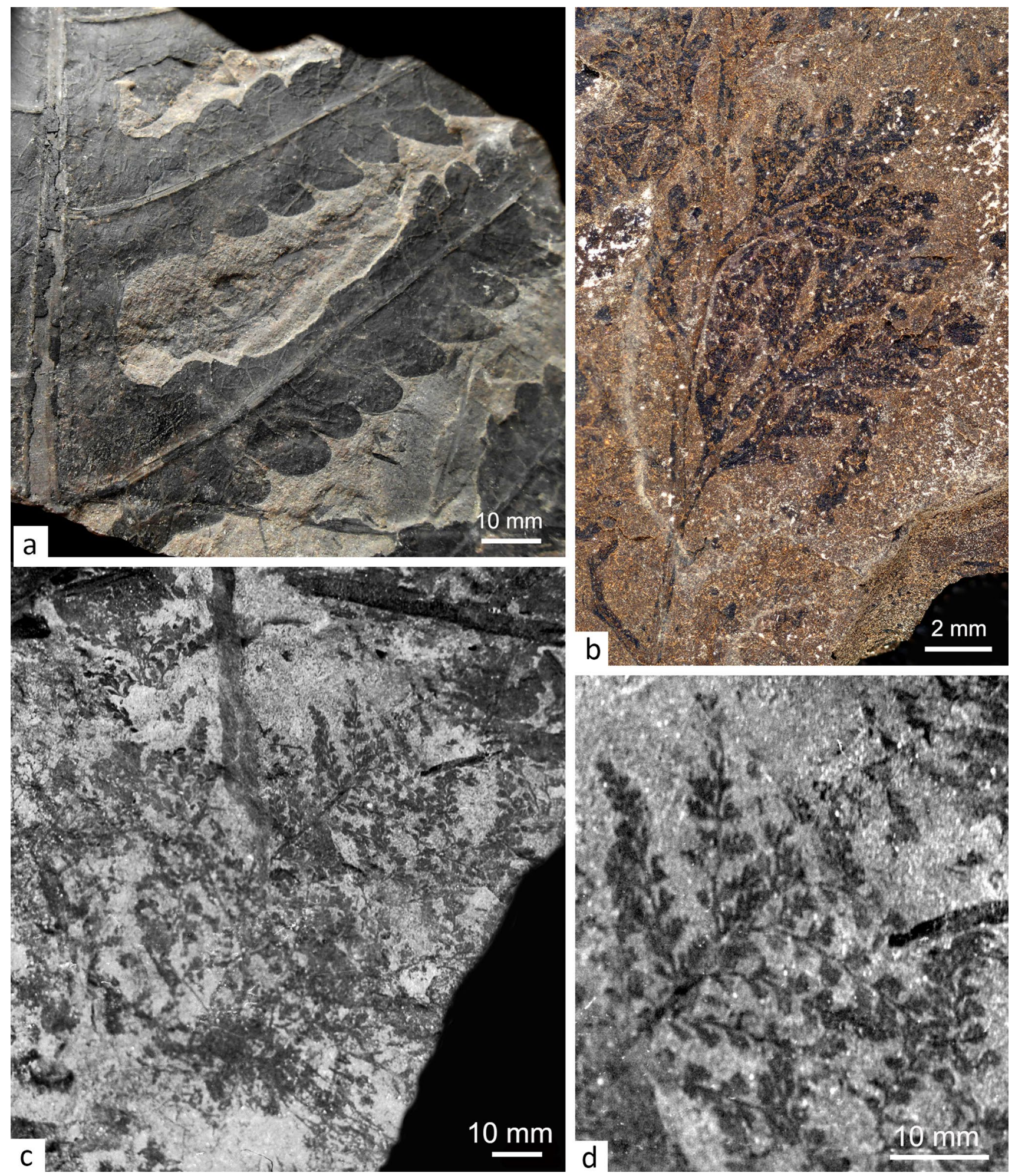

Fig. 9 Ferns of the Early Jurassic of Hungary. a Pinna fragment of Dictyophyllum rugosum Lindley and Hutton 1834 emend. Harris 1961, No. 59.267.1., Komló. b Pinna fragment of Coniopteris sp.,
No. 2001.626.1. (photo MS). c The lost juvenile plant of Coniopteris $s p$. with fragment of rhizome and roots, archive photo. d Detail from c 
89.463.1, 89.465.1-466.1, 89.482.1-483.1, 94.136.1-138.1, 94.231.1, 94.267.1, 94.338.1-339.1, 94.342.1, 94.344.1, 94.397.1, 94.424.1, 94.424.1R, 94.439.1, 94.476.1, 94.487.1, 94.509.1-510.1, 94.549.1-550.1, 94.554.1, 94.663.1, 96.57.1, 96.78.1-81.1, 96.83.1-89.1, 96.132.1, 96.171.1, 96.181.1-184.1, 96.360.1-367.1, 96.480.1, 98.345.1, 98.348.1, 2000.1159.1, 2002.4.1, 2002.136.1 (72 specimens).

Dictyophyllum rugosum Lindley and Hutton 1834 emend. Harris 1961

Figure 9a

Selected synonyms (for more details see Harris 1961).

1834 Dictyophyllum rugosum-Lindley and Hutton: p. 65, pl. 104.

1856-68 Dictyophyllum rugosum Lindley et Hutton-De Zigno: p. 176-178, pl. 23, figs. 1-2.

1867 Dictyophyllum acutilobum-Schenk: p. 77, pl. 19, figs. 3-5, pl. 20, fig. 1.

1922 Dictyophyllum rugosum Lindley et HuttonHamshaw: p. 110-116, figs. 1-5.

1961 Dictyophyllum rugosum Lindley et Hutton-Harris: p. 176-178, pl. 23, figs. 1-2.

1961 Thaumatopteris muensteri (Göppert) NathorstNagy: p. 621, pl. 11, fig. 1.

1961 Thaumatopteris muensteri Göppert var. longissima Schenk-Nagy: p. 621, pl. 13, fig. 3.

1961 Dictyophyllum acutilobum (Braun) SchenkNagy: p. 622.

2002 Dictyophyllum rugosum Lindley et HuttonWang: p. 130, 133, pl. 4, figs. 1-4.

2011 Dictyophyllum rugosum Lindley et Hutton-Kiritchkova and Nosova: p. 55, pl. 4, figs. 4-6, pl. 5, fig. 1 .

Description. The frond fragments are sterile, preserved as separated lobes, only in few specimens the rachis is preserved. The basal part of the fronds is not preserved. The rachis is up to $5 \mathrm{~mm}$ wide. The lobes are $75-85 \mathrm{~mm}$ long and 8-20 mm wide (max. $30 \mathrm{~mm}$ ). They are widely spaced and have almost parallel (or slightly tapering), waved to lobed margins. Secondary lobes may be deeply incised (3-5 $\mathrm{mm}$ ), sometimes even teeth-shaped; their apex is obtuse to subacute. The midrib is distinct, secondary veins form dense irregular, reticulate meshes.

Remarks. Dictyophyllum rugosum differs from D. nilssonii in having longer and deeper (sometimes double) lobed pinnae with more delicate veins. Two specimens with strongly developed teeth-shaped lobes resemble D. acutilobum (Braun) Schenk 1867, a younger synonym of D. nilssonii
(Harris 1931). We attribute the specimens from Mecsek to D. rugosum because of the double lobation (D. nilssonii is never double lobed) and the secondary lobes which are exceptionally regular with acute apices. The specimens attributed by Nagy (1961) to D. acutilobum, T. muensteri (Göppert) Nathorst 1956 and T. muensteri var. longissimi Schenk 1867, after re-examination are included into $D$. rugosum.

Harris (1961) described fertile frond fragments of this species with sessile sporangia (which may form sori of $1-4$ sporangia). The in situ spores $(\sim 40 \mu \mathrm{m}$ diameter $)$ are tetrahedral with thick, smooth walls, a distinct trilete mark with a distinct laesura of the dispersed Deltoidosporites type of spore. Götz et al. (2011) mentioned Deltoidospora for Upper Triassic-Lower Jurassic sediments of Hungary.

Material. BP 89.458.1, 89.465.1, 89.488.1, 94.168.1, 94.273.1, 94.281.1, 94.283.1, 94.335. -336.1, 94.377.1, 94.380.1, 94.383.1, 94.402.1, 94.410.1, 94.412.1-413.1, 94.415.1-416.1, 94.004.1, 94.426.1, 94.429.1, 94.431.1, 94.434.1, 94.436.1, 94.824.1, 94.827.1, 94.829.1, 94.883.1, 96.57.1, 96.69.1, 96.74.1, 96.82.1, 96.185.1, 96.221.1, 96.346.1, 98.791.1, 2002.32.1, 2002.137.1, 2003.464.1, 2004.60.1, 2005.823.1 (41 specimens).

Order Cyatheales Frank in Leunis 1877

Family Dicksoniaceae Schomb. 1848

\section{Genus Coniopteris Brongniart 1848}

\section{Coniopteris sp.}

Figure 9b-d

Description. The most complete fossil corresponds to a juvenile? plant with a rounded rhizome fragment and thin roots (less than $1 \mathrm{~mm}$ wide). The sterile fronds are bipinnate, up to $80 \mathrm{~mm}$ long and $30 \mathrm{~mm}$ wide. The rachis is $0.5 \mathrm{~mm}$ wide, with 8-20 $\mathrm{mm}$ long and up to $5 \mathrm{~mm}$ wide pinnae. Pinnules are slightly catadromic, 2-4 mm long, and 0.5-2.5 mm wide. They are more or less deeply dissected with 3-5 lobes. The aphlebiform pinnules are found at the pinna bases. Fertile fronds are not preserved.

Remarks. The genus Coniopteris is common in the Jurassic of the Northern Hemisphere, although it is more frequent in the Middle Jurassic. Harris (1961) described six species of Coniopteris from the Middle Jurassic of Yorkshire which differ in shape of pinnules and form of fertile fronds. The specimens from the Mecsek Mts. resemble Coniopteris hymenophylloides (Brongniart) Seward 1900 emend. Harris, 1961, because pinnae and pinnules do not overlap and the pinnules are slightly catadromic. The aphlebiform pinnules situated basiscopically are also a typical feature 
of this species (Van Konijnenburg-van Cittert and Morgans 1999). The specimens have also some features of $C$. murrayana (Brongniart) Brongniart emend. Harris 1961 like tapering pinnae and delicate pinnule shape. According to Harris (1961) the fronds of $C$. murrayana are much larger than those of $C$. hymenophylloides, but in Hungarian material the frond size remains unresolved since the most complete specimen corresponds probably to a juvenile plant. The pinnule shape resembles some sterile pinnules of $C$. margaretae Harris 1961, widely represented in Middle Caspian Basin (Kiritchkova and Nosova 2011), but margins of C. margaretae are more deeply and irregularly incised. As a whole plant our specimen resembles Coniopteris braunii Brongniart 1828 as illustrated by Schenk (1867, pl. 6, figs. 6, 7 ), which shows similar juvenile fronds.

Götz et al. (2012) evidenced Cyathidites minor Couper 1958 and Concavisporites parvulus sensu Bona 1995 as dispersed Dicksoniaceae spores in the Upper Triassic-Lower Jurassic of Hungary. Van Konijnenburg-van Cittert (1989) described in situ spores of six Coniopteris species as trilete, subtriangular to triangular in shape, in some species with a margo, in others with a perispore. This would correspond both to the dispersed Concavisporites Pflug in Thomas and Pflug 1953 and Cyathidites Couper 1953 genera.
Material. The described specimen, unfortunately, belonged to a private collection and was lost; only pictures confirm this record. The Hungarian Natural History Museum holds two other specimens which are small fragments of poorly preserved pinnae: BP 2001.626.1, 2001.627.1.

\section{Discussion}

All fern species represented in the Lower Jurassic sediments of the Mecsek Mountains (Hungary) are widely known from numerous localities of the Northern Hemisphere (Table 1). Most are typical elements of Lower Jurassic floras, with the exception of Coniopteris sp., which was more common during the Middle Jurassic. In the Mecsek Mts. their richness is expressed both in a high abundance and species diversity. They are often preserved in fine-grained sediments which permitted a good preservation of the morphology of the fronds, even if the material was highly coalified, impeding the preservation of in situ spores. The high number of fertile and sterile fronds permits proving high intraspecific variability in some taxa. Some species described by Nagy (1961) from the study locality are revised in this paper. This concerns specimens attributed by that author to $P$. braunii that are now included in $C$. denticulata, and Phlebopteris aff. polypodioides, ascribed in this paper to M. braunii.
Fig. 10 Number of fern taxa co-occurring with other plant species

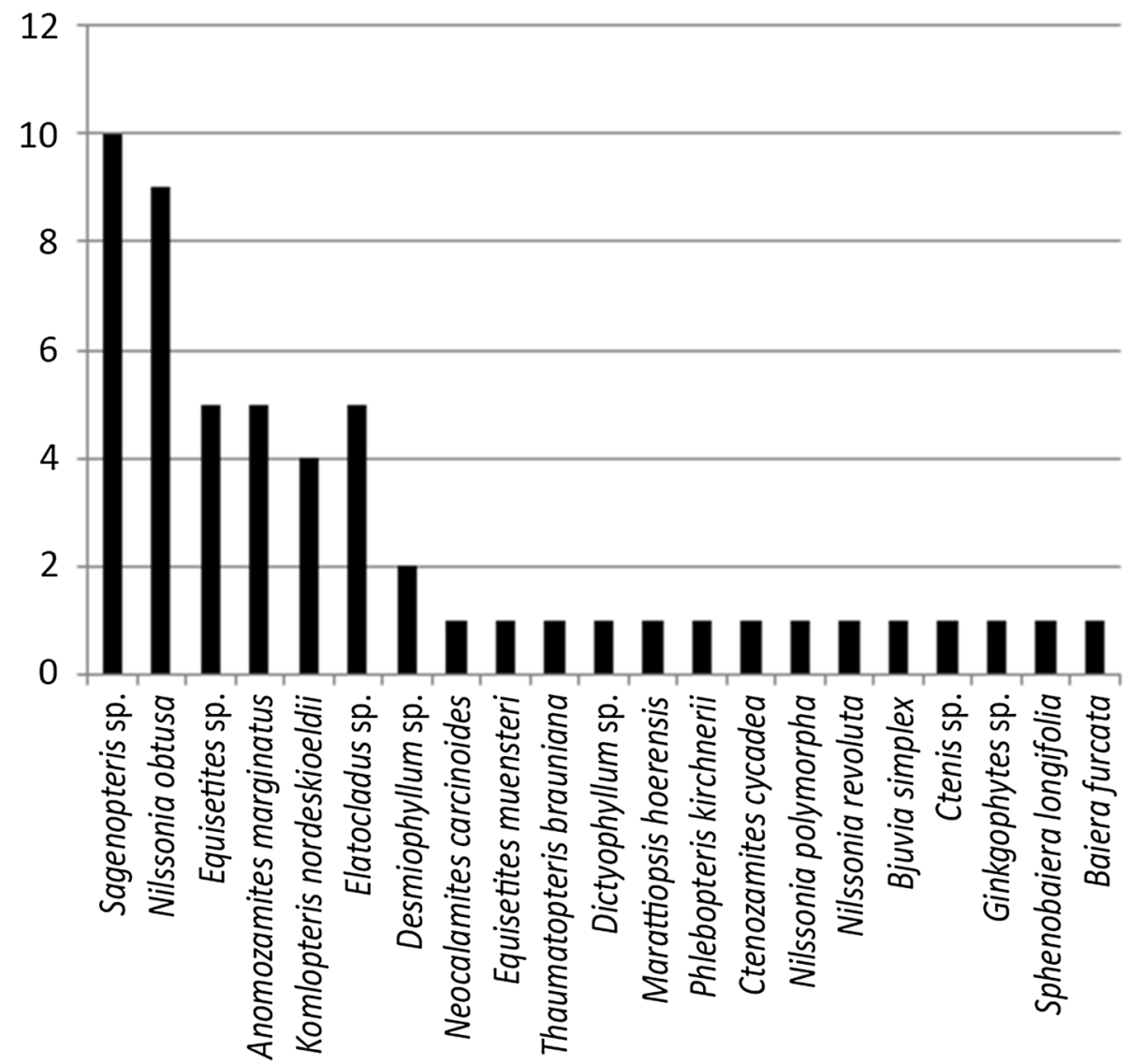


Specimens assigned previously to Dictyophyllum acutiloba, T. muensteri and T. muensteri var. longissima were moved to D. rugosum. Frond fragments described as P. muensteri (Nagy 1961) have been attributed to a new species, P. kirchneri n.sp. Selenocarpus sp., mentioned by Nagy (1961), cannot be revised due to the lack of specimens or any other data like illustration or description.

The Hungarian Jurassic fern assemblage is composed of Marattiaceae (Marattiopsis, one species), Osmundaceae (Todites, Cladophlebis, five species), Matoniaceae (Phlebopteris, Matonia, three species), Dipteridaceae (Thaumatopteris, Clathropteris, Dictyophyllum, four species) and Dicksoniaceae (Coniopteris, one species). Quantitatively, the most common genera are Phlebopteris (214 specimens), Clathropteris (147 specimens), and Cladophlebis (121 specimens), followed by Dictyophyllum (113 specimens), Todites (99 specimens), Thaumatopteris (53 specimens), Marattiopsis (46 specimens), Matonia (10 specimens) and Coniopteris (three specimens). At family level, the Dipteridaceae (313 specimens) would thus be the most abundant group, followed by Matoniaceae (224 specimens) and Osmundaceae
(220 specimens), whereas Marattiaceae (46 specimens) and Dicksoniaceae (three specimens) are rare.

\section{Co-occurrences of the different fern taxa}

Although ferns are abundant and most diverse in the Jurassic of the Mecsek Mts., their co-occurrence with other plants is relatively low. Out of 49 plant fossil taxa only 21 are associated with at least one fern fragment. Among 35 non-fern taxa, seven co-occur with at least two fern species (Fig. 10). A maximum co-occurrence has been observed for Sagenopteris sp., which co-occurs with 10 different fern species, and Nilssonia obtusa, associated with nine species. Equisetites sp., Anomozamites marginatus and Elatocladus sp. co-occur with five species each, Komlopteris nordeskioeldii with four species and Desmiophyllum sp. with two species. Associated with one fern taxon only are the seed fern Ctenozamites cycadea, the cycads Nilssonia polymorpha, Nilssonia revoluta, Bjuvia simplex,

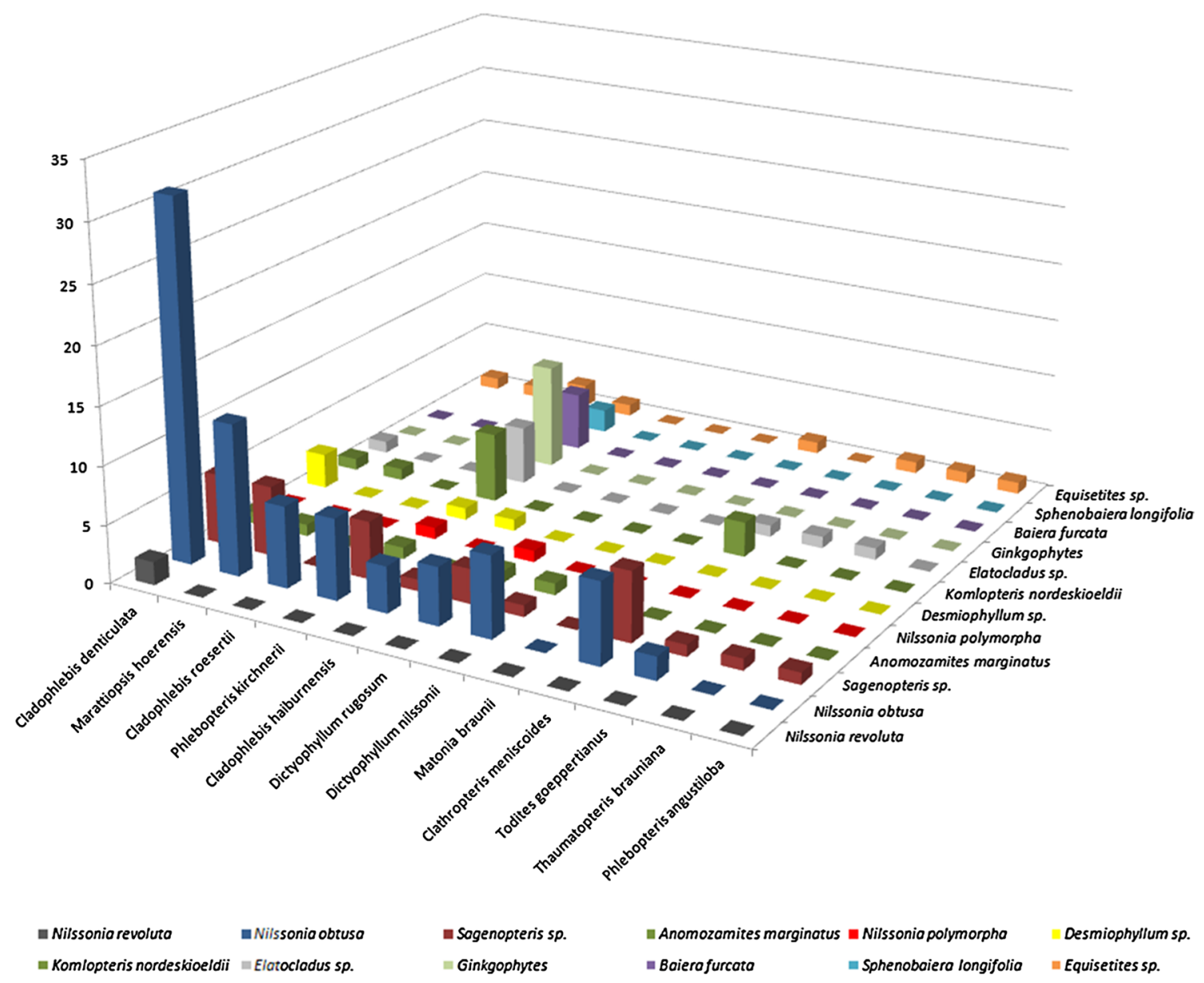

Fig. 11 Co-occurrence of ferns with other plant taxa 
Fig. 12 Percentage of co-occurring fern species
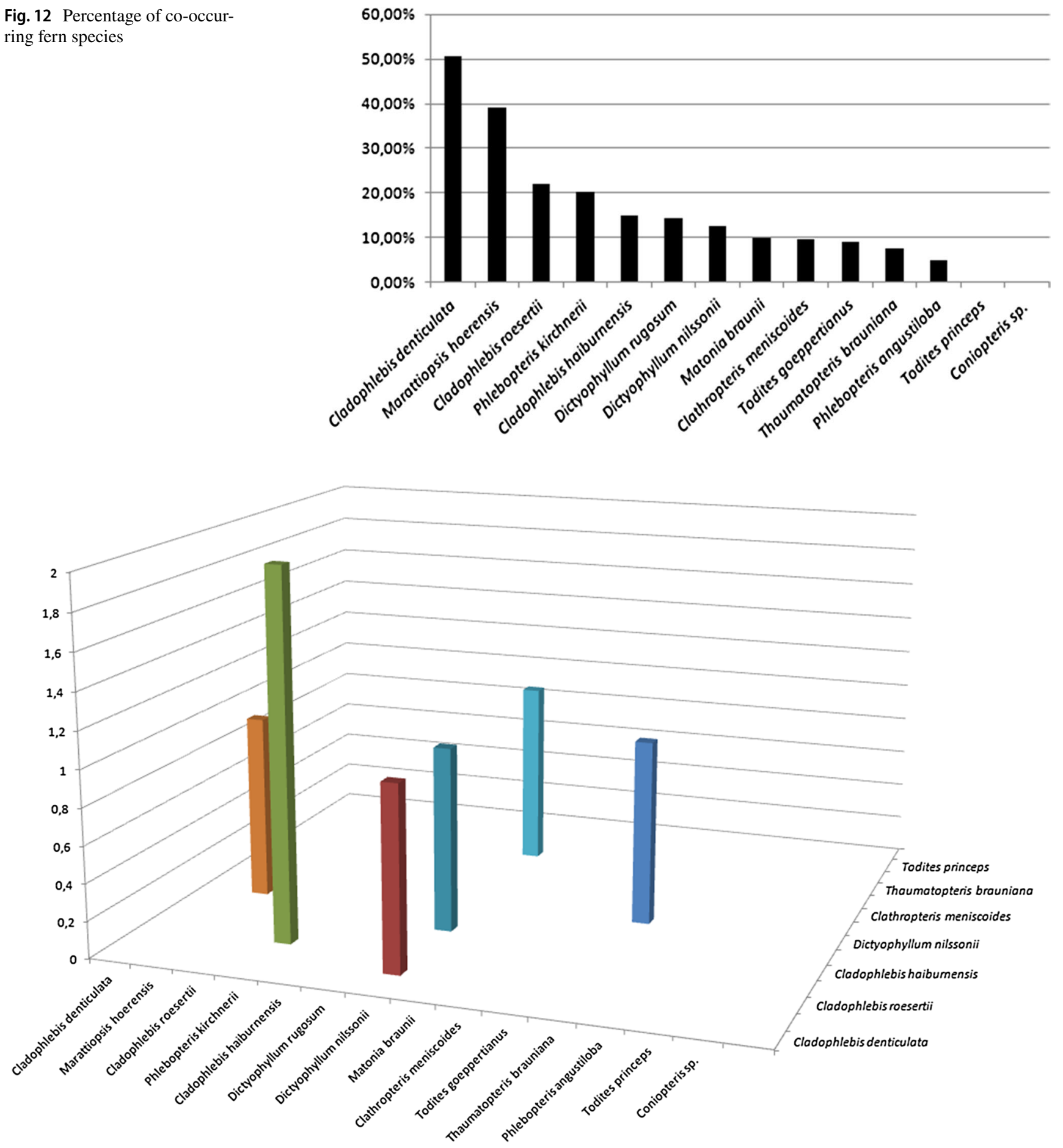

Mlodophiebis denticulato

Morattiopsis hoerensis $=$ Clodophiebis roesertii

Q Phlebopteris kirchnerii @Clodophlebis hoibumensis Dictyophyllum rugosum

= Thaumatopteris brauniana $=$ Phlebopteris angustiloba $\|$ Todites princeps
Dictyophyllum nilssonii EConiopteris sp.

Fig. 13 Co-occurrence between different fern taxa 
Ctenis sp. and the ginkgophytes Sphenobaiera longifolia and Baiera furcata.

Nilssonia obtusa has quantitatively the most co-occurrences with ferns and its frequency is highest with $C$. denticulata (31 specimens) and M. hoerensis (13 specimens). The remaining specimens co-occur fewer then ten times (four in seven specimens, three in six, once five, once four and once two specimens, the rest are associated with single specimens). A relatively high co-occurrence is observed between $P$. kirchneri and the ginkgophytes (16 specimens with indet. ginkgophytes, B. furcata and S. longifolia). This fern species is actually the only one associated with ginkgophyte leaves (Fig. 11).

All ferns show significant disproportion between quantity of co-occurring and not co-occurring samples. The most frequently co-occurring fern species is $C$. denticulata with almost $50 \%$ specimens associated with other plant remains (Fig. 12). M. hoerensis co-occurs for $40 \%$ and C. roessertii and P. kirchneri for $20 \%, C$. haiburnensis, D. rugosum and $D$. nilssonii less than $15 \%, M$. braunii, C. meniscoides, $T$. brauniana are associated for less than $10 \%$ of their specimens, $P$. angustiloba for less than 5\%. Two taxa are not associated with any other remains, Coniopteris sp. and T. princeps, but the former is represented only by three specimens. Seven (out of 14) fern taxa are associated with other fern remains (four pairs); the resulting pairs are $C$. roessertii and P. kirchneri, C. haiburnensis and D. nilssonii, D. nilssoniii and $T$. brauniana, as well as D. rugosum and M. hoerensis.
However, often only single specimens of each species are associated; even the very abundant $P$. kirchneri (associated with 13 different taxa) is associated with $C$. roessertii on two samples only (Fig. 13).

\section{PCA and cluster analyses}

In earlier published statistical analyses carried out on the entire plant assemblage from the Jurassic of the Mecsek Mts., five eco-groups were distinguished (Barbacka 2011) based on the species co-occurrence on the same specimens and sedimentological data. The identified environments were influenced mostly by disturbance and water availability and included (1) moderately disturbed, relatively drier inland areas (Sagenopteris ecogroup); (2) highly disturbed short-lived, moderately wet territories of alluvial deposits (Thaumatopteris ecogroup); (3) moderately disturbed swamps (Komlopteris ecogroup); (4) weakly disturbed, moderately wet canopy (Ptilozamites group) and (5) weakly disturbed wetlands (Ginkgoites ecogroup). Not all fern taxa were used in this analysis. Among the excluded taxa were C. meniscoides, T. princeps, T. goeppertianus and C. roessertii because of their low co-occurrence and low abundance in relation to the other flora elements. $M$. braunii was not identified at that time and P. kirchneri appeared as Phlebopteris sp. Accordingly to the previous study (Barbacka 2011) most ferns had their maximum occurrence in disturbed and

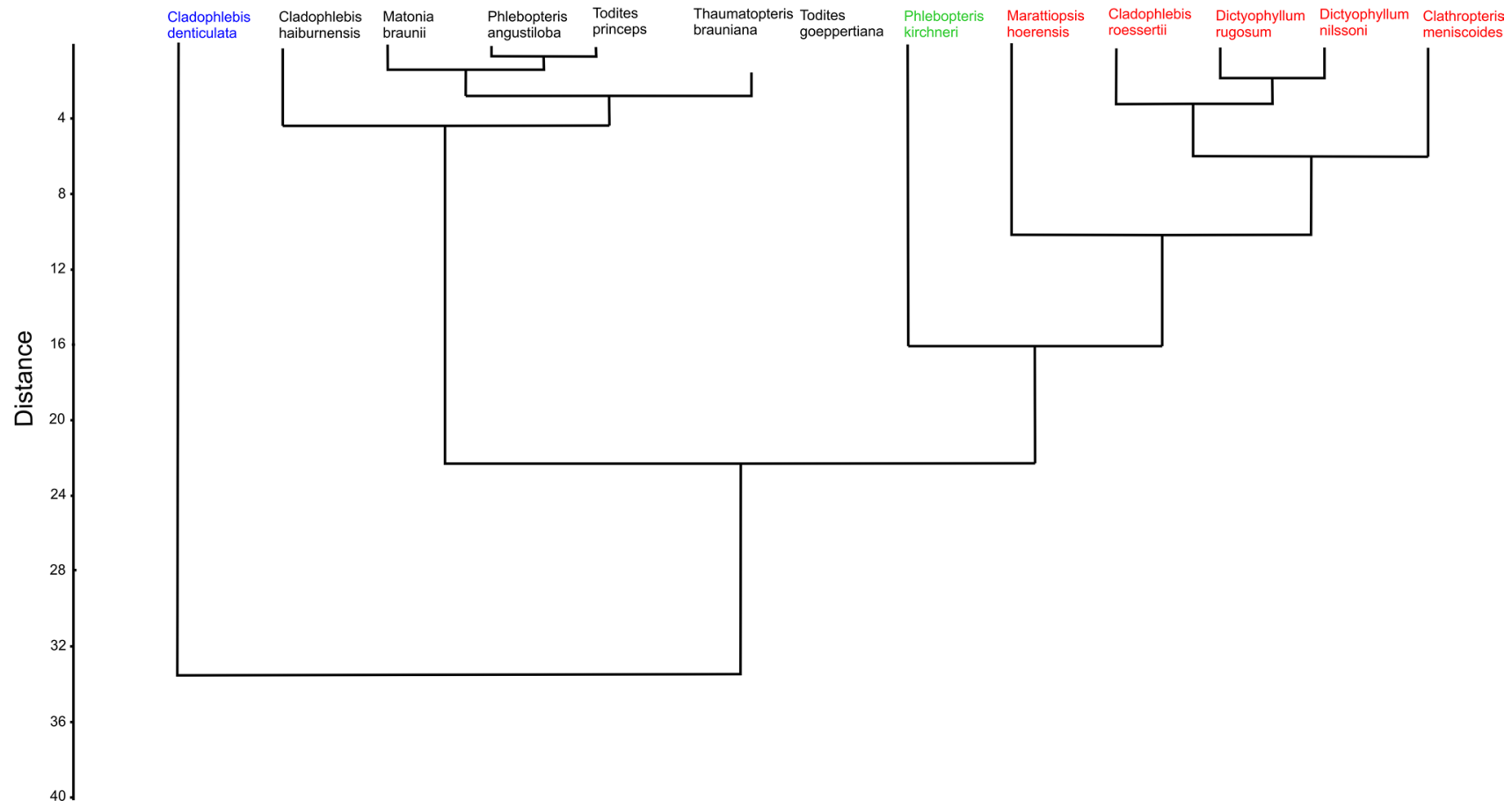

Fig. 14 Dendrogram result of Ward cluster analyses. The different colours represent the different eco-groups of ferns 


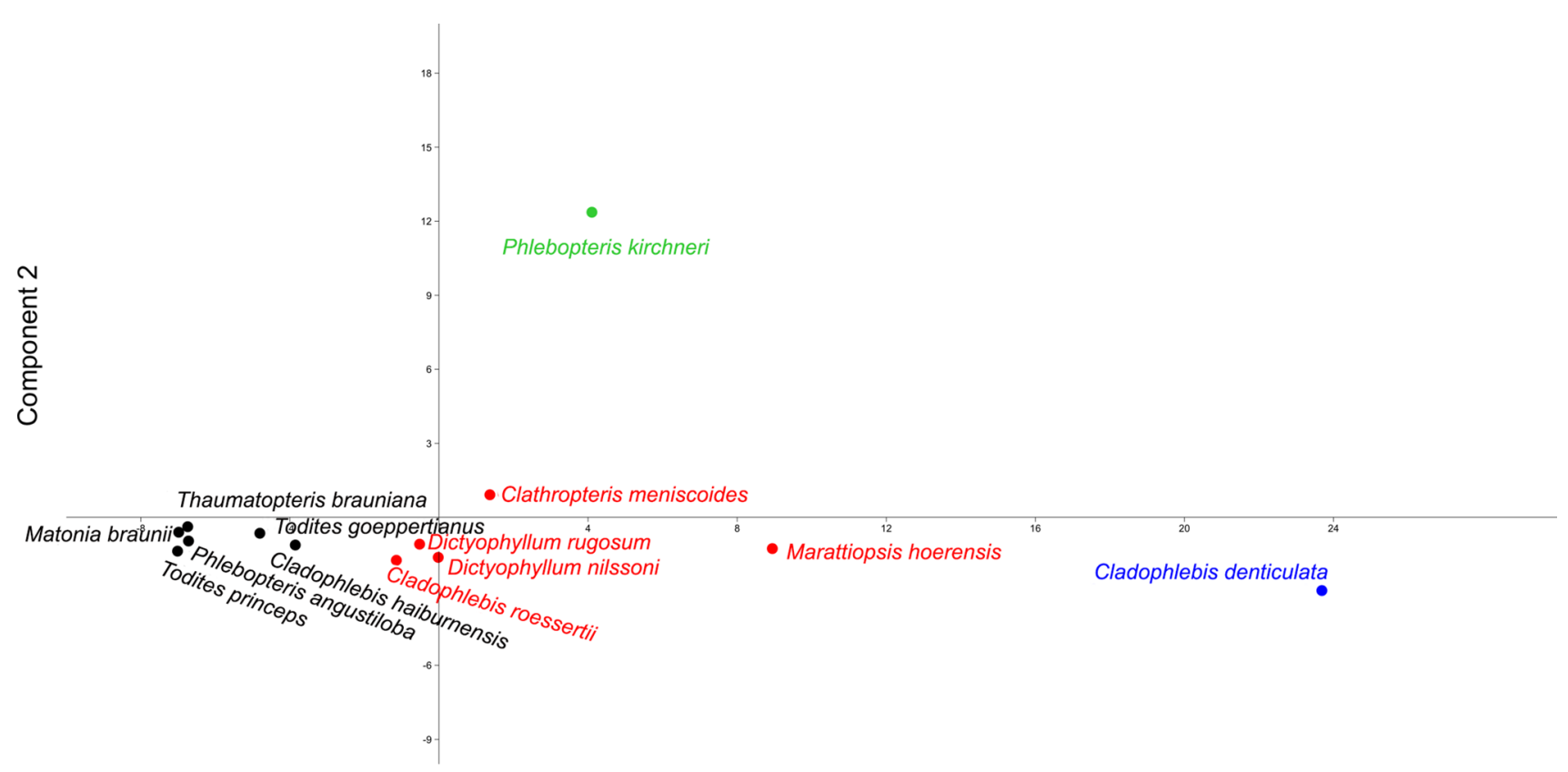

Component 1

Fig. 15 Visualisation of the first two components of PCA analyses. Colours symbolize the eco-groups formed by cluster analyses

rather wet environments (Thaumatopteris ecogroup was represented exclusively by ferns and horsetails), whereas some were connected with drier, and moderately to less disturbed habitats. No fern taxon has its maximum appearance in the wettest, swampy environment (Komlopteris ecogroup) including most of ginkgophytes, although P. kirchneri cooccurs with all types of ginkgophyte remains. The present statistical analysis with special focus on the ferns improves considerably the insight on their interaction, and includes all fern taxa with the exception of Coniopteris sp. because of too low number of specimens.
The cluster analysis based on the co-occurrence of ferns with all other taxa from the localityseparates four major fern groups (Fig. 14). Fern species were differentiated the same way using PCA (Figs. 15, S3). The first group includes $T$. goeppertianus, $T$. brauniana, T. princeps, $P$. angustiloba, $M$. braunii and $C$. haiburnensis. The second group encloses $D$. nilssoniii, D. rugosum, C. roessertii, C. meniscoides and $M$. hoerensis. Both groups are situated in the field 3 of the PCA plot, and close along component 1 , excluding $C$. meniscoides which is placed in field 2, thus showing slight opposition along component 1 and $M$. hoerensis located in the field
Fig. 16 Distribution of co-occuring fern taxa in the ecogroups

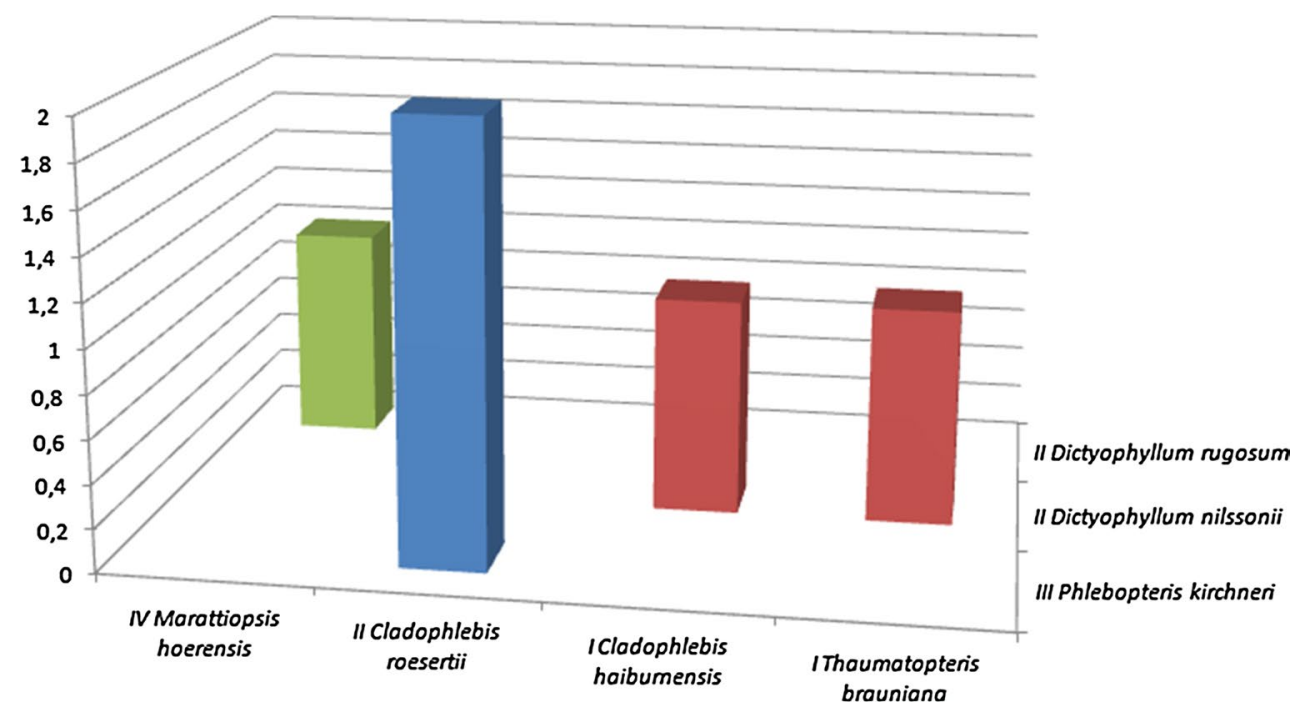


4 , showing a positive trend along component 1 . The third group is monospecific with P. kirchneri and occupies the field 2 , having positive values in component 2 . C. denticulata forms the fourth group, also monospecific, located in field 4 , and spreads to the positive values of component 1 . It is apparent that the groups show a significant dispersion over the plot, reflecting their different requirements/adaptations. For interpretation we used the same environmental factors that were concluded for the whole flora from the Mecsek Mts. (Barbacka 2011), thus the component 1 reflects a wetter (left) to drier (right) environment and component 2 disturbed (bottom) to undisturbed (top) conditions, this attributes most ferns to rather wet and disturbed environment (field 3). In this case, $C$. denticulata would grow in the most dry, and P. kirchneri in the less disturbed habitat. Most taxa are influenced by component 1 , suggesting that moisture is the decisive factor in fern ecological requirements. This is evident by the fact that $\mathrm{PC} 1$ explains $79 \%$ of the total variance while PC2 explains 15\%. The groups 1,2 and 4 are influenced in the same degree by disturbance, but are spread along moisture gradient.

Regarding the co-occurences, the first group represents taxa co-occuring in the lowest degree, while taxa spread along the first two components (P. kirchneri, $C$. denticulata and $M$. hoerensis) are the most associated with other plants. It is noteworthy that the groups do not form common assemblages and are not attributed to a certain type of environment, but to a certain set of environmental conditions. Taxa in the same groups are not necessarily growing together. In fact, the co-occurring fern taxa belong to different PCA groups (see Fig. 16), which means that they could meet on the boundaries of their ecological ranges The Ward cluster analysis reflects the groups from the PCA, but here P. kirch$n e r i$ is close to the second group indicating that the cluster analysis does not detect disturbance as a significant factor.

\section{Suggested environmental requirements of the ferns}

Ecological considerations on fossil ferns are mostly based on comparisons with extant representatives, since only few in situ findings exist to date. Extant Marattiaceae are arborescent plants with large fronds that live under warm and moist circumstances such as understorey in forests. In the Jurassic of Yorkshire, fossil forms occur mainly in floodplain deposits, whereas a tree-fern habit was never demonstrated (Van Konijnenburg-van Cittert 2002). However, our studies suggest for the only marattialean fern taxon of the Hungarian Jurassic, M. hoerensis, drier environments than for most ferns, because of its frequent co-occurence with $N$. obtusa and Sagenopteris sp. (see also Barbacka 2011).
Osmundaceae (Cladophlebis and Todites) are known as small arborescent plants with slender stems (Schenk 1867; Schweitzer 1978; Taylor et al. 2009; Pole 2014) preferring warm and humid environments, such as riverbanks, lake shores, fresh-water marshes, or brackish-water environment near the sea coast (Harris 1961; Vakhrameev 1991; Van Konijnenburg-van Cittert and Van der Burg 1996; Deng 2002; Wang 2002; Van Konijnenburg-van Cittert 2002; Sun et al. 2010). C. denticulata was the most important fern in coal layers in Romania. It colonized areas in the closing stages of the mire development together with $T$. brauniana and $D$. nilssoniii or formed monospecific assemblages (Van Konijnenburg-van Cittert 2002; Popa 1997, 1998, 2000, 2014; Popa and Meller 2009; Barbacka 2011; Barbacka et al. 2015, 2016). However, the Hungarian plant remains were found in all rock types except channel fill deposits, indicating that the habitat of $C$. denticulata extended towards dry and moderately disturbed conditions with a high environmental tolerance (Barbacka and Bodor 2008; Barbacka 2011; Bodor and Barbacka 2012). C. roessertii, on the other hand, shows preferences directed towards slightly wetter conditions. Unfortunately, the low number of specimens preserved does not indicate any clear association with other plants apart from P. kirchneri and N. obtusa. Nonetheless it could have been part of diverse vegetation as suggested for other floras (Harris 1926; Gee 1989).

Cladophlebis haiburnensis and T. goeppertianus lived probably in slightly more disturbed and wetter environments than $C$. roessertii, probably alluvial deposits (islands, forelands), periodically damaged by floodings and occupied by colonizing plants (Barbacka 2011). C. haiburnensis was found in foliated siltstones attributed to lake or swamp deposits, whereas $T$. goeppertianus was found on a wide range of rock types indicating a high environmental adaptation for this species (Barbacka 2011; Bodor and Barbacka 2012). T. princeps occupied, according to the PCA plot, the wettest habitats in Mecsek (Bodor and Barbacka 2012). T. princeps occurred in the Early Jurassic of China and Poland in humid habitats surrounding lakes and rivers (Wang 2002; Wang et al. 2005, Barbacka et al. 2010). Harris (1961) suggested for T. princeps an epiphytic lifestyle, other authors (Schenk 1867; Weber 1968; Batten 1974; Schweitzer 1978; Hesselbo et al. 2003; Barbacka 2011) reconstructed it with quickly growing rhizomes und with short stems $(\max 30 \mathrm{~cm})$ colonizing muddy soils due to the finding of short in situ stems in growth position with attached fronds.

The ecology of the matoniaceous ferns during the Mesozoic is variable. Matoniaceae are known as arborescent ferns (Wang 2002) although some fossil taxa such as P. polypodioides and Matonia pectinata were reconstructed with short stems and an extended rhizome system (Schweitzer 1978). $P$. kirchneri, P. angustiloba and M. braunii from Mecsek could have a similar morphology. Ferns with rather large fronds, 
such as $P$. angustiloba, could have grown under humid conditions in the understorey or as pioneer plants of disturbed, short-lived, moderately wet areas formed by alluvial deposits (Barbacka 2011). Other matonialean ferns were more stressadapted (Van Konijnenburg-van Cittert, 2002). P. kirchneri is the fern with the widest spectrum of co-ocurring plants, both in number of taxa and number of occurrences. Barbacka (2011) attributed it (mentioned as Phlebopteris sp.) due to its large fronds and thin lamina to the undisturbed, moderately wet canopy. On our PCA plot, this species stands out in environmental preferences, being highly tolerant with one of the widest environmental distributions among the ferns (Barbacka 2011). M. braunii occurs in the Early Jurassic of Poland in situ in a flood-plain-backswamp environment at the transition zone between floodplain (crevasse splay-delta) and lacustrine-back-swamp zones (Barbacka et al. 2016). On the PCA plot this species evidences the same requirements as $T$. princeps, in the wettest places grown by ferns.

Dipteridaceae during the Mesozoic occupied mainly humid and temperate-warm to subtropical climate zones. They are considered opportunistic plants colonizing disturbed habitats such as stream sites, riverbanks, exposed ridges and clearings (Cantrill 1995; Van Konijnenburg-van Cittert 2002; Bomfleur and Kerp 2010). The genera Clathropteris, Dictyophyllum and Thaumatopteris are considered herbaceous plants (Schweitzer 1978; Wang 2002; Bomfleur and Kerp 2010). Wang (2002) suggested Dictyophyllum with large fronds to be a dweller of humid environments and low light conditions (understorey). D. nilssoniii and D. rugosum lay in the PCA plot close together in habitats with reduced humidity and with a low degree of disturbance, similar to most ferns. However, the co-occurring N. obtusa, Sagenopteris sp. and A. marginatus are connected to more stabile environments. Barbacka (2011) attributed D. rugosum to the highly disturbed and moderately wet areas formed by alluvial deposits, whereas $D$. nilssonii was part of the weakly disturbed canopy together with $P$. kirchneri. $T$. brauniana has been reconstructed with several metres long horizontally growing rhizomes (Schweitzer 1978) due to its resemblance with Dipteris Reinwardt, 1825. Barbacka (2011) considered this species a colonizer plant of highly disturbed and moderately wet habitats. However our analysis places this species in the wettest and most disturbed habitat similar to $T$. princeps and M. braunii. C. meniscoides was reconstructed in Antarctica as herbaceous understory in open vegetation dominated by bennettitaleans that became a dominant element during the colonization phase of disturbed sites after catastrophic volcanic events (Bomfleur and Kerp 2010). This species was also considered forming large monotypic thickets in disturbed environment in Early Jurassic of Patagonia, as a colonizing plant (Choo et al. 2016). In Hungary C. meniscoides occurs with $N$. obtusa, K. nordeskioeldii,
Sagenopteris sp., Elatocladus sp. and Equisetites sp. and is close to both Dictyophyllum species on the PCA plot.

Extant Dicksoniaceae are tree-ferns in tropical and temperate rain forests, preferring thus warm and humid habitats (Vakhrameev 1991; Van Konijnenburg-van Cittert 2002). Most Mesozoic dicksoniaceous ferns are herbaceous with creeping rhizomes and grew in warm and humid climate zones of the Northern Hemisphere (Europe and Asia; Sun 1986; Deng 1995; Deng and Chen 2001). During the Lower Jurassic the dicksoniaceous ferns, such as Coniopteris, were rather small plants colonizing the margins of swamps (Wang 2002; Deng and Lu 2006).

\section{Concluding remarks}

Ferns are the most diverse group in the Mecsek Mts., both considering their number (more than 800 samples; about $16 \%$ of total number of collected material) and diversity (14 out of 55 taxa). Five families were recognized so far from the locality including Dipteridaceae (48\% of the collected ferns), Matoniaceae (25\%), Osmundaceae (21\%), Marattiaceae (6\%) and Dicksoniaceae (three specimens). Most taxa are attributed to relatively wet (non swampy) and disturbed habitats, but $C$. denticulata shows significant tendency to drier conditions and P. kirchneri sp. nov. to more stabil environment with better This was interpreted as growing in extended arborescent to herbaceous monospecific thickets in areas threatened by flooding along channels and river banks.

The Early Jurassic sediments of the Mesek Mts. locality represent delta plain environment with a slow transition from delta to lake and lake-lagoonal environment in combination with fluctuations of the sea level due to several transgressions and regressions. The territory was rich in water, with peat-forming marshes along the river branches or lakes (Van Konijnenburg-van Cittert 2002; Barbacka and Bodor 2008; Barbacka 2011; Götz et al. 2011). The climate was humid and warm (Nagy and Nagy 1969; Paál-Solt 1969; Némedi Varga 1995, 1998; Barbacka 2011). The low degree of fragmentation and the very good preservation in most plant remains suggest a (par-)autochthonous deposition of the plant remains.

The ferns occupied more or less wet territories in this generally humid delta plain, although not all taxa were peat-forming and restricted to such environments (e.g., Van Konijnenburg-van Cittert 2002). Most humid areas were colonized by ferns with the lowest co-occurences, forming monospecific thickets such as T. brauniana, $P$. angustiloba, M. braunii, T. princeps, T. goeppertianus, and C. haiburnensis. Among them are both herbaceous and arborescent forms. A second group with low co-occurences and herbaceous taxa with very large fronds occupied the less humid environments (C. roessertii clusters in the same group, but had different 
preferences). These forms co-occur mainly with $N$. obtusa and Sagenopteris sp.; only $C$. meniscoides shows higher associations with Komlopteris nordenskioeldii and Elatocladus sp. Since the co-occurrences are relatively low, it is probable that they formed also monospecific bushes, but in mixed communities.

Three taxa have separate positions on the PCA plot and are mostly co-occurring with other plants. M. hoerensis, although considered as a member of group 2, occupies a separate position within the group due to its high association with N. obtusa and Sagenopteris sp., and less frequent association with $K$. nordenskioeldii, A. marginatus and Equisetites sp. Considering N. obtusa as a rather small plant, whereas the morphology of Sagenopteris is unclear, and $M$. hoerensis having wide fronds, it is highly probable that the fern formed larger clumps within mixed assemblages. $C$. denticulata, a tree fern, was associated with $N$. obtusa in highest degree (three times more than $M$. hoerensis). It seems that $N$. obtusa is an indicator of dry environments. $C$. denticulata is one of the most commonly co-occurring fern species, confirming that this fern was more related to other plants within the community. The fern with the highest co-occurrence with other taxa, and the only one associated with ginkgophytes, is P. kirchneri. This herbaceous plant was connected to less disturbed habitats. Since the associated plants include many trees, like ginkgophytes, $K$. nordenskioeldii (Barbacka and van Konijnenburg-van Cittert 1998), or Elatocladus sp., this fern may be attributed to the understorey.

The palaeoecology of ferns from the Mecsek Mts. is comparable to extant ferns growing in tropics and their life strategy. According to Sharp et al. (2010), ferns very often form extended bushes that can be stable for a long time, because some of them can inhibit with allelopatic excudates the growth of trees and other plants. Their living fronds create dense shadow and dry fronds together with thick rhizomes cover the soil, inhibiting dispersal of seeds and seedlings. Ferns can easily colonize and expand instable habitats with their rhizomes (floods provide areas for colonization). Ferns thus form dense and self-perpetuating populations that can last a long time (thousands of years) because they inhibit changes in species composition, increase stabilization of soil and produce soil. The reproductive strategy by spores and rooting of trunk buds guarantees expansive growing. Thick soil cover and slowly decompositing fronds or other organs have a long-term impact on succession and soil development (Sharp et al. 2010).

Acknowledgements Authors thank Tamás Henn for the making us available the specimen of Dictyophyllum rugosum from the Natural Historicy Collection of Komló, for the study and illustration, Julia Tamás for the regression analysis, Marian Szewczyk for the pictures, and Agnieszka Sojka for drawings. Hendrik Nowak (Museum of Nature South Tyrol) is thanked for his critical reading of the Manuscript. MB was supported by the W. Szafer Institute of Botany, Polish Academy of Sciences, though its statutory funds. EK received financial support for her project CZ-TAF-4535 "The diversity of the Jurassic floras of Europe" from the SYNTHESYS3 Project http://www.synthesys.info/ which is financed by European Community Research Infrastructure Action under the FP7 "Capacities" Programme". This paper is also part of the UNESCO-IUGS IGCP Project 632 'Continental Crises of the Jurassic: Major Extinction Events and Environmental Changes within Lacustrine Ecosystems'. EB acknowledges the Geological and Geophysical Institute of Hungary (National project: 2015-2017/11.1) for research fundings. The authors thank the Department of Innovation, Research and University of the Autonomous Province of Bozen/ Bolzano for covering the Open Access publication costs.

Open Access This article is distributed under the terms of the Creative Commons Attribution 4.0 International License (http://creativeco mmons.org/licenses/by/4.0/), which permits unrestricted use, distribution, and reproduction in any medium, provided you give appropriate credit to the original author(s) and the source, provide a link to the Creative Commons license, and indicate if changes were made.

\section{References}

Antevs, E. 1919. Die Liassische Flora des Hörsandsteins. Kungliga Svenska Vetenskapsakademiens Handlingar 59 (8): 3-61.

Ash, S.R. 1991. A New Jurassic Phlebopteris (Plantae, Filicales) from the Wallowa Terrane in the Snake River Canyon, Oregon and Idaho. Journal of Paleontology 65 (2): 322-329.

Barbacka, M. 1991. New data about Liassic fossil plants in the Mecsek Mountains (South Hungary). Annales Musei historico-naturalis hungarici 83: 17-23.

Barbacka, M. 1994a. Komlopteris Barbacka, gen. nov., a segregate from Pachypteris Brongniart. Review of Palaeobotany and Palynology 83: 339-349.

Barbacka, M. 1994b. Pachypteris banatica (Humml) Doludenko from Liassic locality in Mecsek Mountains, Hungary. Acta Palaeobotanica 34 (1): 5-19.

Barbacka, M. 2001. The cycads from the Hungarian Liassic. Revue de paléobiologie Genève 20: 525-541.

Barbacka, M. 2002. The Liassic Ginkgoales from the Mecsek Mountains, Hungary. Revue de paléobiologie 21 (2): 697-715.

Barbacka, M. 2009. Sphenophyta from the Early Jurassic of the Mecsek Mts., Hungary. Acta Palaeobotanica 49 (2): 221-231.

Barbacka, M. 2011. Biodiversity and reconstruction of Early Jurassic flora from the Mecsek Mountains (southern Hungary). Acta Palaeobotanica 51 (2): 127-179.

Barbacka, M., and E. Bodor. 2008. Systematic and palaeoenvironmental investigations of fossil ferns Cladophlebis and Todites from the Liassic of Hungary. Acta Palaeobotanica 48 (2): 133-149.

Barbacka, M., and K. Bóka. 2014. Ovule-containing cupules belonging to the Early Jurassic pteridosperm, Komlopteris nordenskioeldii (Nathorst) Barbacka. Review of Palaeobotany and Palynology 210 (2014): 102-112.

Barbacka, M., and J.H.A. van Konijnenburg-van Cittert. 1998. Sun and shade leaves in two Jurassic species of pteridosperms. Review of Palaeobotany and Palynology 103: 209-221.

Barbacka, M., Z. Jadwiga, and E. Wcisło-Luraniec. 2010. Taxonomy and palaeoecology of the Early Jurassic macroflora from Odrowąż, central Poland. Acta Geologica Polonica 60 (3): 373-392.

Barbacka, M., E. Bodor, A. Jarzynka, E. Kustatscher, G. Pacyna, M.E. Popa, G.G. Scanu, F. Thévenard, and J. Ziaja. 2014. European 
Jurassic floras: Statistics and palaeoenvironmental proxies. Acta Palaeobotanica 54 (2): 173-175.

Barbacka, M., M.E. Popa, J. Mitka, E. Bodor, and G. Pacyna. 2015. Relationships between ecosystems and plant assemblages as responses to environmental conditions in the Lower Jurassic of Hungary and Romania. Acta Palaeobotanica 55 (1): 3-17.

Barbacka, M., M.E. Popa, J. Mitka, E. Bodor, Z. Püspöki, and R.W. McIntosh. 2016. A quantitative approach for identifying plant ecogroups in the Romanian Early Jurassic terrestrial vegetation. Palaeogeography, Palaeoclimatology, Palaeoecology 446: 44-54.

Batten, D.J. 1974. Wealden palaeoecology from the distribution of plant fossils. Proceedings of the Geologists' Association 85 (4): 433-458.

Beudant, F.S. 1822. Voyage minéralogique et géologique en Hongrie pendant l'année 1818. Paris: Chez Verdiére.

Bodor, E., and M. Barbacka. 2008. Taxonomic implications of Liassic ferns Cladophlebis Brongniart and Todites Seward from Hungary. Palaeoworld 17: 201-214.

Bodor, E., and M. Barbacka. 2012. The remarkable world of the ferns in the Mecsek Coal Formation with special focus on the genera Todites and Cladophlebis (SW Hungary). e-Acta Naturalia Pannonica 3: 1-10.

Bomfleur, B., and H. Kerp. 2010. The first record of the dipterid fern leaf Clathropteris Brongniart from Antarctica and its relation to Polyphacelus stormensis Yao, Taylor et Taylor nov. emend. Review of Palaeobotany and Palynology 160: 143-153.

Bomfleur, B., I.H. Escapa, E.L. Taylor, and T.N. Taylor. 2013. Proposal to conserve the name Marattiopsis (fossil Marattiaceae) with a conserved type. Taxon 62 (3): 637-638.

Braun, K.F.W. 1840. Verzeichnis der in der Kreis-NaturalienSammlung zu Bayreuth befindlichen Petrefacten. Leipzig: Leopold Voss.

Brongniart, A.T. 1828b. Prodrome d'une histoire des végétaux fossiles. Paris: Levrault.

Brongniart, A.T. 1849. Tableau des genres de végétaux fossiles considérés sous le poin de vue de leur classification botanique edt de leur distribution géologique. Paris: Imprimere de L. Martinet.

Cantrill, D.J. 1995. The occurrence of the fern Hausmannia Dunker (Dipteridaceae) in the Cretaceous of Alexander Island, Antarctica. Alcheringa 19: 243-254.

Chabrerie, O., K. Laval, P. Puget, S. Desaire, and D. Alard. 2003. Relationship between plant and soil microbial communities along a successional gradient in a chalk grassland in north-western France. Applied Soil Ecology 24: 43-56.

Choo, T.Y.S., I.H. Escapa, and B. Bomfleur. 2016. Monotypic colonies of Clathropteris meniscioides (Dipteridaceae) from the Early Jurassic of central Patagonia, Argentina: Implications for taxonomy and palaeoecology. Palaeontographica B 294: 85-109.

Cittert, Van Konijnenburg-van, and H.S. Morgans. 1999. The Jurassic flora of Yorkshire. London: The Palaeontological Association.

Currano, E.D., C.C. Labandeira, and P. Wilf. 2010. Fossil insect folivory tracks paleotemperature for six million years. Ecological Monographs 80: 547-567.

Császár, G. (ed.). 1997. Basic litostratigraphic units of Hungary. Charts and short descriptions. Budapest: The Geological Institute of Hungary.

Daber, R. 1962. A Weichselia-Stiechleria-Matoniaceous community within the Quedlinburg Estuary of Lower Cretaceous age. Journal of the Linnean Society (Botany) 384: 75-85.

De Zigno, A. 1856-68. Flora fossilis formationis oolithicae. 2. Padova: Pubblicazione dell'Università di Padova.

Deng, S. 1995. Early Cretaceous Flora from Huolinhe Basin, Inner Mongolia. Beijing: Geological Publishing House. (in Chinese with English summary).
Deng, S. 2002. Ecology of the Early Cretaceous ferns of the Northeast China. Review of Palaeobotany and Palynology 119: 93-112.

Deng, S., and F. Chen. 2001. The Early Cretaceous Filicopsida from Northeast China. Beijing: Geological Publishing House. (in Chinese with English summary).

Deng, S., and Y. Lu. 2006. The Mesozoic Dicksoniaceous ferns: Characteristics, distribution, origin and evolutionary trends. Global Plant Letters 1 (1): 9-29.

Dobruskina, I.A. 1994. Triassic Floras of Eurasia. Wien: Springer.

Escapa, I.H., B. Bomfleur, R. Cuneo, and R. Scasso. 2015. A new marattiaceous fern from the Lower Jurassic of Patagonia (Argentina): The renaissance of Marattiopsis. Journal of Systematic Palaeontology 13 (8): 677-689.

Földi, J. 1967. A Mecsek hegységi felsószinemuri képzódmények szintezési lehetósége. Annales Instituti Geologici Publici Hungarici 1965: 133-148.

Gee, C. 1989. Revision of the Late Jurassic/Early Cretaceous flora from Hope Bay, Antarctica. Palaeontographica B 213 (4-6): 149-214.

Givulescu, R., and M.E. Popa. 1989. Aninopteris formosa n.gen. new sp., a new Liassic Matoniaceous genus and species from Anina, Banat, Romania. Review of Palaeobotany and Palynology 104: 51-66.

Gothan, W. 1914. Die unter-liassische (rhätische) Flora der Umgegend von Nürnberg. Abhandlungen der Naturhistorischen Gesellschaft 19: 91-186.

Góczán, F. 1956. A komlói liász feketekószéntelepek azonositására irányuló pollenanalitikai vizsgálatok (Pollen analysis as a method for coal layers identification in the Liassic of Komló). Annales Instituti Geologici Publici Hungarici 45 (1): 135-166. (in Hungarian).

Göppert, H.R. 1841. Die Gattungen der fossilen Pflanzen verglichen mit denen der Jetztwelt und durch Abbildungen erläutert. Bonn: Henry und Cohen.

Götz, A.E., K. Ruckwied, and M. Barbacka. 2011. Palaeoenvironment of the Late Triassic (Rhaetian) and Early Jurassic (Hettangian) Mecsek Coal Formation (south Hungary): Implications from macro- and microfloral assemblages. Paleobiodiversity and Paleoenvironment 91 (2): 75-88.

Guignard, G., K. Bóka, and M. Barbacka. 2001. Sun and shade leaves? Cuticle ultrastructure of Jurassic Komlopteris nordenskioeldii (Nathorst) Barbacka. Review of Palaeobotany and Palynology 114: 191-208.

Halle, T.G. 1913. The Mesozoic flora of Grahan Land. Wissenschafliche Ergebnisse der schwedischen. Südpolar-expedition (19011903). Stockholm: Lithographisches Institut des Generalstabs.

Hammer, R., D.A.T. Harper, and P.D. Ryan. 2001. PAST: Paleontological statistics software packagefor education and data analysis. Palaeontologia Electronica 4 (1): 1-9.

Hantken, M. 1878. A Magyar Korona Országáinak széntelepei és szénbányászata. [Coal mines and coal production in the countries of the Hungarian Crown]. Budapest: Légrády Testvérek.

Harris, T.M. 1926. The Rhaetic flora of Scoresby Sound, East Greenland. Meddelelser om Grønland 68: 45-147.

Harris, T.M. 1931. The fossil flora of Scoresby Sound East Greenland-Part 1: Cryptogams (exclusive of Lycopodiales). Meddelelser om Grønland 85 (2): 1-102.

Harris, T.M. 1961. The Yorkshire Jurassic Flora. I Thalophytapteridophyta. London: Trustees of the British Museum (Natural History).

Harris, T.M. 1980. The Yorkshire Jurassic fern Phlebopteris Braunii (Goeppert) and its reference to Matonia R. Br. Bulletin of the British Museum (Natural History) Geology 33 (5): 295-310.

Herbst, R. 1971. Revision de las espacies Argentinas del genero Cladophlebis. Ameghiniana 8: 265-281. 
Hesselbo, S.P., H.S. Morgans-Bell, J.C. McElwain, P. McAllister Rees, S.A. Robinson, and E.C. Ross. 2003. Carbon-cycle perturbation in the Middle Jurassic and accompanying changes in the terrestrial paleoenvironment. Journal of the Geological Society 111: 259-276.

Jarzynka, A. 2016. Fossil flora of Middle Jurassic Grojec clays (southern Poland). Raciborski's original material reinvestigated and supplemented. II. Pteridophyta. Osmundales. Acta Palaeobotanica 56 (2): 83-221.

Johansson, N. 1922. Die rätische Flora der Kohlengruben bei Stabbarp und Skromberga in Schonen. Kungliga Svenska Vetenskapsakademiens Handlingar 63 (5): 1-78.

Kawasaki, S. 1939. Second addition to the older Mesozoic plants in Korea. Bulletin of the Geological Survey of Tyosen 4 (3): 1-69.

Kilpper, K. 1964. Über Rät/Lias Flora aus dem nördlichen Abfall des Alburs-Gebirges in Nordiran. I: Bryophyta und pteridophyta. Palaeontographica, B 114 (1-3): 1-78.

Kiritchkova, A.I., and N.W. Nosova. 2011. Jurassic continental deposits of the Middle-Caspian basin. I: Main cuts, stratigraphy, flora (Bryophyta, Lycopodiophyta, Equisetophyta, Polypodiophyta, Pteridospermae). St. Peterburg: VNIGRI.

Kimura, T. 1959. Mesozoic plants from the Ivamuro Formation (Liassic) Tone. Gun, Gumma Prefecture, Japan. Bulletin of the Senior High School attached to the Tokyo University of Education 3: $1-58$.

Kostina, E.I., and M.P. Doludenko. 1997. Ferns from Middle Jurassic of the Kansk Coal Basin (Siberia). Paleontological Journal 31 (2): 178-188.

Kovács, J., P. Tanos, J. Korponai, I. Kovácsné Székely, K. Gondár, I. Gondár-Sőregi, and G. Hatvani. 2012. Analysis of water quality data for scientists. In Water quality and water pollution: Evaluation of water quality data, Rijeka, eds. K. Voudouris, D. Voutsa, 65-94. Tech Open Access Publisher. Available at: https://www. intechopen.com/books/water-quality-monitoring-and-assessment /analysis-of-water-qualitydata-for-researchers.

Krasser, F. 1922. Zur Kenntnis einiger fossiler Floren des unteren Lias der Sukzessionsstaaten von Österreich-Ungarn. der Akademie der Wissenschaften (Mathematisch-naturwissenschaftliche Klasse) 130: 345-373.

Kräusel, R. 1958. Die Juraflora von Sassendorf bei Bamberg. I Sporenpflanzen. Senckenbergiana lethaea 39 (1/2): 67-103.

Krystofovich, A.N. 1912. Mesozoic plant remains from the Eastern Ural. Bulletin Commission geologique Saintt Petersbourgh 31: 489-498.

Kvaček, J. 2014. Marattiopsis vodrazkae sp. nov. (Marattiaceae) from the Campanian of the Hidden Lake Formation, James Ross Island, Antarctica. Acta Musei Nationalis Pragae Series B, Historia Naturalis 70 (3): 211-218.

Landis, E.R., T.J. Rohrbachera, C.E. Barkera, B. Fodor, and G. Gombar. 2003. Coalbed gas in the Mecsek Basin, Hungary. International Journal of Coal Geology 54 (2003): 41-55.

Lindley, J., and W. Hutton. 1831-37. The fossil flora of Great Britain of figures and descriptions of the vegetable remains found in a fossil state, 1. London: James Ridgway.

Lundblad, B. 1950. Studies in the Rhaeto-Liassic Floras of Sweden: I: 1 Pteridophyta, Pteridospermae, and Cycadophyta from the mining district of NW Scania. Kungliga Svenska Vetenskapsakademiens Handlingar Series 41 (8): 5-82.

Nagy, E., and J. Nagy. 1969. Stratigraphie. In Unterlias-Kohlenserie des Mecsek-Gebirges, Geologie, ed. E. Nagy, vol 51, pp 280287. Budapest: Müszaki Könyvkiadó.

Nagy, I.Z. 1961. Liassic plant remains of the Mecsek Mountains. Annales Instituti Geologici Publici Hungarici 49 (2): 609-658.

Nathorst, A.G. 1875. Fossila växter från den stenkolsförande formationen vid Pålsjö i Skåne. Geologiska Föreningens i Stockholm Förhandlingar 2 (10): 373-392.
Nathorst, A.G. 1878. Bidrag till Sveriges fossila flora. Floran vid Höganäs och Helsingborg. Kungliga Svenska Vetenskapsakademiens för Handlingar 16 (7): 1-53.

Némedi Varga, Z. 1995. A pécsi feketekőszén-terület földtani és hegységszerkezeti viszonyai [The area of Coal-Formation near Pécs and its geological relations]: 39-64. In Mecseki feketeköszén kutatása és bánya földtana. [Investigations of black coal and geology of coal measures in the Mecsek Mts.], ed. Z. Varga Némedi, Miskolc: Miskolci Egyetem Központi Könyvtár és Levéltár.

Némedi Varga, Z. 1998. A Mecsek- és a Villányi-Egység jura képződményeinek rétegtana [The stratigraphy of the Jurassic units of the Mecsek Mountains and Villanyi Mountains]: 319-336. In Magyarország geológiai képzódményeinek rétegtana [The stratigraphy of the Hungarian geological units], eds. I. Bérci and Jámbor A., Budapest: A MOL Rt és a MÁFI kiadványa. (in Hungarian).

Oishi, S. 1932. The Rhaetic plants from the Nariwa District Prov. Bithcu (Okayama Prefecture). Japanese Journal of the Faculty of Science, Hokkaido Imperial University 4: 257-379.

Oishi, S. 1939-40. The Mesozoic Floras of Japan. Journal of Faculty of Science, Hokkaido Imperial University (series 4) 5(2-4): 123-480.

Paál-Solt, M. 1969. Kohlenpetrographie. In Unterlias-Kohlenserie des Mecsek-Gebirges, Geologie, ed. E. Nagy, 51(2): 473-575. Budapest: Müszaki Könyvkiadó.

Pole, M. 2014. http://www.mikepole.com/2014/06/22/cladophlebisnew-zealands-mesozoic-weed/).

Popa, M.E. 1997. Liassic ferns from the Steierdorf Formation, Anina, Romania. In Proceedings 4th European palaeobotanical and palynological conference, 58, 139-148.

Popa, M.E. 1998. The Liassic continental flora of Romania: Systematics, stratigraphy and paleoecology. Acta Botanica Horti Bucurestensis 1997-1998: 177-184.

Popa, M.E. 2000. Early Jurassic land flora of the Getic Nappe. Bucharest: Faculty of Geology and Geophysics, University of Bucharest. (unpublished).

Popa, M.E. 2014. Early Jurassic bennettitalean reproductive structures of Romania. Palaeobiodiversity and Palaeoenvironments 94: $327-362$.

Popa, M.E., and B. Meller. 2009. Review of Jurassic plants from the Anina (Steierdorf) Coal Mining Area, South Carpathians, in the Collections of the Geological Survey of Austria. Jahrbuch der Geologischen Bundesanstalt 149 (4): 487-498.

Popp, O. 1863. Der Sandstein von Jägersburg bei Forchheim und die in ihm vorkommenden fossilen Pflanzen. Neues Jahrbuch für Mineralogie, Geologie und Paläontologie 1863: 399-417.

R Core Team (2013). R: A language and environment for statistical computing. R Foundation for Statistical Computing, Vienna, Austria. http://www.R-project.org/.

Raciborski, M. 1890. Flora retycka w Tatrach. Rozprawy Wydziatu Matematyczno-Przyrodniczego Akademii Umiejętności Kraków 21: $243-260$

Raciborski, M. 1894. Flora kopalna ogniotrwałych glinek krakowskich. Część I. Rodniowce (Archaegoniatae). Pamiętnik matematyczno-przyrodniczy Akademii Umiejętności Kraków 18: $1-101$.

Reymanówna, M. 1963. The Jurassic flora from Grojec near Cracow in Poland. Part I. Acta Palaeobotanica 4 (2): 9-48.

Saporta, G.De. 1873. Les végétaux fossiles de l'Ètade Rhétien en Scanie. Annales des sciences géologiques 1873: 74-99.

Schenk, A. 1867. Die fossile Flora der Grenzschichten des Keupers und Lias Frankens. Wiesbaden: Kreidel.

Schimper, W.P. 1869. Traitè de Paléontologie végétale ou la flore du monde primitif dans ses rapports avec les formations géologiques 
et la flore du monde actuel. Tome premier. Paris: Bailliére J.B. et Fils.

Schweitzer, H.-J. 1978. Die räto-jurassischen Floren des Irans und Afganistans. 5. Todites princeps, Thaumatopteris brauniana und Phlebopteris polypodioides Palaeontographica, Abteilung B 168 (1-3): 1-79.

Schweitzer, H.-J., M. Kirchner, J.H.A. van Konijnenburg-van Cittert, J. van der Burgh, and A.R. Ashraf. 2009. The Rhaeto-Jurassic flora of Iran and Afghanistan. 14. Pterophyta-Leptosporangiatae. Palaeontographica, Abteilung B 279: 1-108.

Senterre, B., G. Rouhan, I. Fabrei, C. Morel, and M.J.M. Christenhusz. 2014. Revision of the fern family Marattiaceae in the Seychelles with two new species and a discussion of the African Ptisana fraxinea complex. Phytotaxa 158 (1): 57-75.

Seward, A.C. 1911. The Jurassic flora of Sutherland. Transaction of the Royal Society of Edingburg 47 (23): 643-709.

Sharp, J.M., K. Mechltreter, and L.R. Walker. 2010. Ecological importance of ferns. In Fern ecology, eds. K. Mechltreter, L.R. Walker, and J.M. Sharp. Cambridge: Cambridge University Press.

Shi, G.R. 1993. Multivariate data analysis in palaeoecology and palaeobiogeography - a review. Palaeogeography, Palaeoclimatology, Palaeoecology 105 (3-4): 199-234.

Sternberg, C. von 1820-38. Versuch einer geognostisch-botanischen Darstellung der Flora der Vorwelt. Leipzig and Prague.

Spicer, R.A., and C.R. Hill. 1979. Principal components and correspondence analyses of quantitative data from a Jurassic plant bed. Review of Palaeobotany and Palynology 28: 273-297.

Sun, B.N. 1986. A Preliminary Study of Middle Jurassic Fossil Plants from Yaojie Coal-Field of Lanzhou. Journal of Lanzhou University (Natural Sciences) 22: 113-118. (in Chinese with English abstract).

Sun, G., Y. Miao, V. Mosbrugger, and A.R. Ashraf. 2010. The Upper Triassic to Middle Jurassic strata and floras of the Junggar Basin, Xinjiang, Northwest China. Palaeobiodiversity and Palaeoenvironment 90 (3): 203-214.

Szente, I. 1992. Early Jurassic Mollucs from the Mecsek Mountains (S. Hungary). A preliminary study. Annales of the University of Science of Budapest, Section Geology 29: 325-343.

Taylor, T.N., E.L. Taylor, and M. Krings. 2009. Paleobotany: The biology and evolution of fossil plants. Amsterdam: Elsevier Science.

Teodoridis, V., J. Kovar-Eder, and P. Mazouch. 2011. Integrated plant record (Ipr) vegetation analysis applied to modern vegetation in South China and Japan. Palaios 26 (10): 623-638.

Tralau, H. 1965. Phlebopteris angustiloba (Presl) Hirmer et Hörhammer (Matoniaceae) from "Olstrop" Shaft, Bjuv. Scania. Botaniska Notiser 118 (4): 373-376.

Thomas, H.H. 1913. The fossil flora of the Cleveland district of Yorkshire. I. The flora of Marske quarry. Quartary Journal of the Geological Society 69: 1-223.
Thomas, H.H. 1922. On some new and rare Jurassic plants from Yorkshire. V. Fertile specimens of Dictyophyllum rugosum I. and II. Proceedings of the Cambridge Philosophical Society 21: 1-110.

Vakhrameev, V.A. 1991. Jurassic and Cretaceous floras and climates of the earth. Cambridge: Cambridge University Press.

Van der Burgh, J., and J.H.A. Van Konijnenburg-van Cittert. 1984. A drifted flora from the Kimmeridgian (Upper Jurassic) of Lothbeg Point, Sutherland, Scotland. Review of Palaeobotany and Palynology 43: 359-396.

Van Konijnenburg-van Cittert, J.H.A. 1975. Some notes on Marattia anglica from the Jurassic of Yorkshire. Review of Palaeobotany and Palynology 20: 205-214.

Van Konijnenburg-van Cittert, J.H.A. 1993. A review of the Matoniaceae based on in situ spores. Review of Palaeobotany and Palynology 78: 235-267.

Van Konijnenburg-van Cittert, J.H.A. 1989. Dicksoniaceous spores in situ from the Jurassic of Yorkshire, England. Review of Palaeobotany and Palynology 61: 273-301.

Van Konijnenburg-van Cittert, J.H.A. 1996. Two Osmundopsis species and their sterile foliage from the Middle Jurassic of Yorkshire. Palaeontology 39 (3): 719-731.

Van Konijnenburg-van Cittert, J.H.A. 2002. Ecology of some Late Triassic to early Cretaceous ferns in Eurasia. Review of Palaeobotany and Palynology 119: 113-124.

Van Konijnenburg-van Cittert, J.H.A., and J. van der Burg. 1989. The flora from the Kimmeridgian (Upper Jurassic) of Culgower, Sutherland, Scotland. Review of Palaebotany and Palynology 61: 1-51.

Van Konijnenburg-van Cittert, J.H.A., and J. Van der Burg. 1996. Review of the Kimmeridgian flora of Sutherland, Scotland, with reference to the ecology and in situ pollen and spores. Proceedings of the Geologists' Association 107: 97-105.

Watson, J. 1969. A revision of the English Wealden fora, I. CharalesGinkgoales. Bulletin of the British Museum Natural History (Geology) 17: 207-254.

Wang, Y. 2002. Fern ecological implications from the Lower Jurassic in Western Hubei, China. Review of Palaeobotany and Palynology 119: 125-141.

Wang, Y., Z. Cao, and F. Thévenard. 2005. Additional data on Todites (Osmundaceae) from the Lower Jurassic with special references to the palaeogeographical and stratigraphical distributions in China. Geobios 38 (2005): 823-841.

Weber, R. 1968. Die fossile Flora der Rhät-Lias-Übergangsschichten von Bayreuth (Oberfranken) unter besonderer Berücksichtigung der Coenologie. Erlanger Geologische Abhandlungen 72: 3-73.

Zeiller, R. 1903. Flore fossile des gites de charbon du Tonkin. Paris: Imprimerie Nationale. 